International Review of Social History 43 (1998), pp. 3I-78

(C) 1998 Internationaal Instituut voor Sociale Geschiedenis

\title{
Guilds, Social Mobility and Status in Sixteenth-Century Ghent
}

JOHAN DAMBRUYNE*

Summary: This article investigates the relationship between social mobility and status in guilds and the political situation in sixteenth-century Ghent. First, it argues that Ghent guilds showed neither a static picture of upward mobility nor a rectilinear and one-way evolution. It demonstrates that the opportunities for social promotion within the guild system were, to a great extent, determined by the successive political regimes of the city. Second, the article proves that the guild boards in the sixteenth century had neither a typically oligarchic nor a typically democratic character. Third, the investigation of the houses in which master craftsmen lived shows that guild masters should not be depicted as a monolithic social bloc, but that significant differences in status and wealth existed. The article concludes that there was no linear positive connection between the duration of a master craftsman's career and his wealth and social position.

\section{INTRODUCTION}

Until recently the early modern European guilds were usually depicted in the historiography as occupational organizations not only hindering the economic development of cities but also hindering the social improvement of a large number of townspeople. Guilds were surrounded by an aura of protectionism, exclusivism and conservatism. The generational continuity in the guilds and the discrimination between masters' children and outsiders was strongly emphasized. However, recent investigations show that guilds with a numerus clausus and a preponderance of masters' children were not the rule but rather the exception in pre-industrial society. ${ }^{\mathrm{I}}$ From the traditional viewpoint guilds were no channels of social mobility. ${ }^{2}$ The reason

* I wish to thank Ian Archer, Marc Boone, Ian Gadd, Catharina Lis, Hugo Soly and the anonymous referees of this journal for their helpful comments on an earlier version of this article.

I. M. Prak, "Ambachtsgilden vroeger en nu", NEHA-Jaarboek voor economische, bedrijf-en techniekgeschiedenis, 57 (Amsterdam, 1994), pp. 29-30; M. Sonenscher, Work and Wages. Natural Law, Politics and the Eighteenth-Century French Trades (Cambridge, I989), pp. I24-I26. One of the first Belgian historians to question the exclusivism of the guilds was J.-P. Sosson, "La structure sociale de la corporation médiévale. L'exemple des tonneliers de Bruges de I350 à I500”, Belgisch Tijdschrift voor Filologie en Geschiedenis, 44 (1966), pp. 457-478.

2. In early modern society there were several channels that served as social ladders: education, marriage, priesthood, etc. Yet the most important one was the choice of occupation. Concerning 
why guilds are often depicted so negatively has something to do with the fact that both sociologists and some historians depict the entire preindustrial society as an immobile society in order to emphasize the contrast with the mobile industrial society. ${ }^{3}$ Other historians who studied the textile and construction guilds were quite right to stress the downward social mobility in the guilds during the Ancien Régime. No matter how important these economic sectors may have been, they were not representative of all the town guilds. For it is common knowledge that textile and construction were the two branches of industry in which the proletarianizing process manifested itself most strongly. It is only during the last twenty years that historians have examined the opportunities for upward mobility within the town guild system. ${ }^{4}$ In a fascinating article Christopher Friedrichs pointed out that the opportunities for social improvement among master craftsmen depended on their economic status. As long as the masters had control over their means of production, they could improve their social position. ${ }^{5}$ In the meantime it has been proved conclusively that social mobility was an important instrument to guarantee social harmony and stability in a municipal society. ${ }^{6}$

The aim of this article is to shed some light on the opportunities for

marriage, see for example W. Prevenier (ed.), Marriage and Social Mobility in the Late Middle Ages (Ghent, 1989).

3. D. Rose (ed.), Social Stratification and Economic Change (London, 1988), pp. II-38; P. Burke, History and Social Theory (Cambridge, 1992), p. 64. Also in the most recent survey of the history of Ghent the authors typify late medieval Ghent (1360-1540) as a rigid and, as far as the professional aspect is concerned, immobile society: W. Prevenier and M. Boone, "The 'City-State' Dream", in J. Decavele (ed.), Ghent. In Defence of a Rebellious City (Antwerp, 1989), p. 88. This emphasis on social immobility in medieval and early modern society is also found in, among others, M. Mitterauer, Grundtypen alteuropäischer Sozialformen. Haus und Gemeinde in vorindustriellen Gesellschaften (Stuttgart, 1979), pp. 33-34, and W. Schulze and M. Gabel (eds), Ständische Gesellschaft und soziale Mobilität (Munich, 1988).

4. See S. Rappaport, Worlds Within Worlds: Structures of Life in Sixteenth-Century London (Cambridge, 1989); idem, "Social Structure and Mobility in Sixteenth-Century London", London Journal, 9 (1983), pp. I07-135 and Io (1984), pp. I07-134; C.R. Friedrichs, Urban Society in an Age of War: Nördlingen, I580-1720 (Princeton, 1979); E.J. Shephard, "Social and Geographic Mobility of the Eighteenth-Century Guild Artisan: An Analysis of Guild Receptions in Dijon, 1700-90", in S.L. Kaplan and C.J. Koepp (eds), Work in France. Representations, Meaning, Organization, and Practice (Ithaca and London, 1986), pp. 97-130; K. Van Quathem, "Sociale mobiliteit en machtsverdeling in het Brugse schoenmakersambacht (1570-1790)", in C. Lis and H. Soly (eds), Werken volgens de regels. Ambachten in Brabant en Vlaanderen, I500-I80o (Brussels, 1994), pp. I07I34.

5. C.R. Friedrichs, "Capitalism, Mobility and Class Formation in the Early Modern German City", Past and Present, 69 (1975), pp. 24-49.

6. Rappaport, Worlds, p. 387; Friedrichs, Urban Society, pp. 29I-292. Other historians, like Ian Archer, stress the importance of social relations in explaining a society's stability. See the fascinating study of I.W. Archer, The Pursuit of Stability. Social Relations in Elizabethan London (Cambridge, I99I). 
social improvement within the Ghent guild system as well as on the social status of the masters. There are several reasons why we focus on sixteenthcentury Ghent. First of all, Ghent was the second biggest city in the Habsburg Netherlands. ${ }^{7}$ Furthermore, sixteenth-century Ghent was considered to be the main political adversary of the monarch in the municipal domain, and it was characterized by political instability, rebellion and the breakthrough of Protestantism. The first part of the article focuses on upward mobility. We will deal with this subject from two juridical points of view: on the one hand the access to mastership will be examined and on the other the access to the guild board. The central point in the argument is the question to what extent political and institutional developments in sixteenth-century Ghent determined the opportunities for upward mobility within the guilds.

From a political-institutional point of view Ghent society in the sixteenth century was characterized by four periods of rule, the breaking-points being the Concessio Carolina in I540, the coup of the Calvinist revolutionaries in I577, and the reconciliation in 1584 (retrocession of the city to the Spanish King, Philip II). ${ }^{8}$ Whereas the city and the guilds were, to a large extent, autonomous and had considerable political power between I500-I540 and I $577-1584$, they were completely submitted to royal authority between I54OI577 and 1584-1600.9 After the Concessio Carolina the guilds were no longer officially represented in the municipal governing bodies (the two councils of aldermen, the Collation or Broad Council) and hence they were excluded from political power. ${ }^{10}$ At the same time, the guild board was drastically

7. Although accurate population figures are unavailable, it is generally assumed that during the first eighty-five years of the sixteenth century the population of Ghent fluctuated between 40,000 and 50,000 inhabitants. After 1584 the city's population diminished to 30,000: Jan de Vries, European Urbanization, I500-1800 (London, 1984), p. 272. At the beginning of the sixteenth century Ghent ranked among the twenty-eight largest cities of Western and Eastern Europe: R. Mols, "Population in Europe 1500-I700", in C.M. Cipolla (ed.), The Fontana Economic History of Europe. The Sixteenth and Seventeenth Centuries, 2 (Glasgow, 1976), pp. 42-43.

8. In consequence of the Ghent revolt against Charles V in 1539-1540, the emperor imposed a new "constitution" on the city: the Concessio Carolina, which reformed profoundly the political and institutional structures of the city. See J. Decavele and P. Van Peteghem, "Ghent 'Absolutely' Broken”, in J. Decavele (ed.), Ghent. In Defence of a Rebellious City (Antwerp, 1989), pp. I07-II3. 9. Charles V pursued the same policy with regard to the cities and guilds in his German Empire: Friedrichs, "Capitalism", p. 35. See for example the subjection of the guilds in Augsburg in I548: C.-P. Clasen, Die Augsburger Weber: Leistungen und Krisen des Textilgewerbes um I6oo (Augsburg, I98I), pp. 82-85, 237-260, 286-289. Also in France the absolutist monarchs tightened their grip on the guilds in the sixteenth century: E. Coornaert, Les corporations en France avant 1789 (Paris, I94I), pp. I24-I26.

Io. Since the introduction of the so-called "regime of the three members" in the second half of the fourteenth century the guilds had numerical preponderance in all the political institutions of the city. Under this system political power was divided among three social groups: the "burghers" (noblemen and rentiers), the "small guilds" (an umbrella organization coordinating fifty-three guilds predominantly working for the local and regional markets) and the "weavers" (an organi- 
reformed: the position of dean (deken) was abolished and replaced by that of head (overste); the number of jurors (gezworenen) was reduced to two. Unlike the deans the heads were chosen directly by the aldermen (schepenen van de keure) and the bailiff (hoogbaljuw) (the monarch's representative). Furthermore, the heads were chosen not from among the masters but from among the notables of the city (noblemen, rentiers, people practising liberal professions). That way both the monarch and the city council could strengthen their grip on the guilds. Under Calvinist rule (I577-I584) the guilds were again part of the city council and the position of dean was restored, but after the reconciliation the guilds quit the political scene forever.

The point of departure of the mobility investigation is the Concessio Carolina. By enacting this new "constitution" Charles V put a check on the heavy conditions of admittance to mastership. The emperor reduced the admission fee to the Ghent guilds to the modest sum of 240 gr. $^{. I I}$ In his magisterial study on the social history of Ghent, Hans Van Werveke argued that it would be sensible to examine the real impact of the Concessio Carolina on admittance to the guilds. ${ }^{12}$ But so far this interesting question has remained unanswered. We shall therefore try to find out to what extent the Concessio Carolina actually resulted in a considerable increase in the number of masters and, in other words, whether the situation in Ghent differed from the traditional viewpoint presented in the literature, according to which opportunities for social improvement within the guilds decreased in the course of the sixteenth century. ${ }^{13}$ In connection with that we will study the change in the proportion of masters' children to non-masters' children being admitted to the guilds and the proportion of male to female members. By studying the opportunities for being admitted to the guild board we want to find out first of all whether the corporate boards were composed demo-

zation grouping together the six guilds of the woollen cloth industry). The standard work concerning the regime of the three members is M. Boone, Gent en de Bourgondische hertogen, ca.1384-ca.1453. Een sociaal-politieke studie van een staatsvormingsproces (Brussels, I990).

II. All amounts in this article are expressed in Flemish groats (gr.). I pound Flemish groats $=240$ Flemish groats $=\mathrm{I} .5$ pound Brabant groats $=6$ guilders. $\mathrm{I}$ guilder or florin $=20$ stuivers $=40$ Flemish groats.

I2. It would be interesting to examine to what extent the other articles of the Concessio Carolina resulted in social and economic benefits during our period, and particularly the article making it easier to gain access to mastership of a guild. This is no trivial exercise, however: H. Van Werveke, Gand. Esquisse d'histoire sociale (Brussels, 1946), p. 75.

I3. For the southern Netherlands see E. Scholliers and C. Vandenbroeke, "Structuren en conjuncturen in de Zuidelijke Nederlanden I400-I800", in Algemene Geschiedenis der Nederlanden, 5 (Haarlem, 1980), pp. 302-303; R. Van Uytven, "What is New Socially and Economically in the Sixteenth-Century Netherlands", Acta Historiae Neerlandicae, Studies on the History of the Netherlands, 7 (1974), pp. 29-30; idem, "Sociaal-economische evoluties in de Nederlanden vóór de Revoluties (veertiende-zestiende eeuw)", Bijdragen en Mededelingen betreffende de Geschiedenis der Nederlanden, 87 (1972), p. 75; E. Scholliers, "Vrije en onvrije arbeiders voornamelijk te Antwerpen in de XVIe eeuw", Bijdragen voor de Geschiedenis der Nederlanden, II (1956), pp. 285-322. 
cratically or oligarchically. The issues that are dealt with here are: what percentage of the masters held a seat on the board? What was the average waiting time between mastership and a first mandate? What about the frequency of offices? Was it mostly masters' children or non-masters' children who held a seat on the board? Did certain families predominate? With regard to this aspect of social mobility we will try to find out whether the situation after 1540 differed greatly from the one before 1540 .

In the second part of our study we want to focus on the social status of the guild masters. The central point in our approach of this issue is the houses in which masters lived. First of all the intention is to give an average picture of the positions held by masters in the hierarchy of houses, and this will be done by means of the reconstructed land register of the city of Ghent of $157 \mathrm{I}-1572$. This investigation partly allows us to inquire into the degree of social differentiation within and between the guilds. Finally we want to approach this issue more dynamically. By means of a prosopographic analysis of two generations of masters we will examine to what extent the masters' occupational seniority determined the value of their house. In other words: did masters with a long record of service live in more expensive houses than their younger colleagues?

Up to now the Ghent guilds of the sixteenth century have hardly been studied at all. This is probably because of the very limited amount of source material available. The sixteenth-century guild archives are far from complete. Especially with respect to the period before 1540 there is very little adequate material available for an investigation of social mobility. ${ }^{14}$ In the light of the quality of the very few records of membership that have been preserved - they are the main source material for this study-it was decided to limit the investigation to six guilds. Three of them belong to the production sector (brewers, tailors and stocking makers) and the other three belong to the commercial sector (mercers, grocers and cheesemongers). ${ }^{15}$ Before presenting the results of our investigation, we need to give a brief explanation of the economic importance of the guilds investigated.

The Ghent brewers' guild had a monopoly for brewing, initially two, and from 1585 , four types of beer. Beer was an important consumable, especially for the lower social groups who could not afford wine. The eco-

I4. The confiscation of the guild archives by Charles V in 1540 is significant in this context. In I578 part of the original registers were returned.

15. All public records of the guilds are kept in the City Archives of Ghent. All documents referred to in this article are held by the City Archives of Ghent. Our main sources are the membership registers of the brewers (series I60, no. 6), mercers (series I78, no. I), tailors (series I9I, nos I and 2), stocking makers (series 165 , no. 2), cheesemongers (series $171 / 1$, no. I) and grocers (series 172 , nos 3 and 4). For a survey of the gaps in the membership rolls see Appendix I. The gaps in the membership registers could be partly filled using the annual lists of the guild boards (I544-1600), drawn up by the municipal government (series $279 / 2$, no. I), and the guilds' deeds in the alderman's registers (series 30I). 
nomic and fiscal importance of beer is clearly proved by the considerable part of city revenues coming from several taxes on the production and consumption of beer. ${ }^{16}$ In the course of the sixteenth century Ghent's beer production decreased. ${ }^{17}$ Although production was primarily intended for the local market, about a quarter of annual production was exported..$^{18}$ The tailors' guild had a monopoly on making and selling all sorts of custommade outerwear. The field of activity of the stocking makers' guild was limited to making and selling stockings and breeches. ${ }^{19}$ The grocers' guild had a monopoly on the trade in all kinds of food and medicinal herbs, ${ }^{20}$ and in addition the masters were allowed to bake herb cakes. ${ }^{2 \mathrm{I}}$ The cheesemongers' guild controlled the retail trade in cheese and butter, and were also allowed to sell dried fruit (figs and raisins). ${ }^{22}$ The mercers played an important role in providing the citizens with a wide range of products, mostly of foreign manufacture. It was not without reason that the city council called the mercers' guild in 1599 eene van den principaelste van deser stede (one of the most important guilds of the city). ${ }^{23}$ The trading qualifications of these retailers were very extensive: they were allowed to trade both ordinary goods and luxury goods. ${ }^{24}$ Except for the brewers, the masters

I6. In sixteenth-century Ghent, the average contribution of beer taxes to total city revenue was 43 per cent: P. De Commer, "De brouwindustrie te Gent, I505-1622", Handelingen der Maatschappij voor Geschiedenis en Oudheidkunde te Gent, 35 (I98I), p. IIO.

I7. During the first half of the sixteenth century the average annual output of beer was about 95,000 tonnes, between I570-1584 it was about 89,000 tonnes and after 1587 about 57,500 tonnes: P. De Commer, "De brouwindustrie te Gent, I505-1622", Handelingen der Maatschappij voor Geschiedenis en Oudheidkunde te Gent, 37 (1983), p. I23.

I8. Ibid., p. I44.

19. L. Minard-Van Hoorebeke, Description de méreaux et jetons de présence, etc. des gildes et corps de métiers, églises, etc., tome I, Monographie des gildes et corps de métiers de la ville de Gand (Ghent, I877), pp. 132, I35. For the occupational differences between the tailors and the stocking makers, see the article by H. Deceulaer, "Guildsmen, Entrepreneurs, and Market Segments: The Case of the Garment Trades in Antwerp and Ghent (Sixteenth to Eighteenth Centuries)”, in the present issue of the International Review of Social History.

20. Such as pepper, sugar, mustard, oil of olives, cinnamon, ginger, saffron, cumin, treacle, anise, cloves, nutmegs, almonds, prunes, currants, figs, raisins, allspice, tartar, senna, liquorice and white soap: F. De Potter, Gent, van den oudsten tijd tot heden. Geschiedkundige beschrijving der stad (Ghent, I882-I9OI), 3, p. 323.

2I. The herb cakes had to taste redelic naer huerlieder cruidt and had to weigh one pound: University Library of Ghent, manuscript 58, p. 223.

22. Ibid., p. IIo. Farmers and foreign merchants were allowed to sell only dairy products that had not been adulterated or weighed: series $172 / \mathrm{I}$, no. I, f. $75 \mathrm{v}$. From various petitions we learn that in the sixteenth century the cheesemongers met with considerable unfair competition from Dutch merchants: series 156 bis, no. 30 .

23. Ibid., no. $38 / 3$.

24. Mercers traded in metalware (knives, scissors, pins, nails, keys, locks, tin and copper work, etc.), precious metalware (gold and silver ware, jewellery), leatherware (belts, bags, sheaths, purses, gloves, laces, etc.), textiles (silk, cotton, woollen, linen and mixed fabrics, coloured textiles, passementerie) and in clothing (clothes stitched or embroidered with gold, silk-woven belts, girdles, 
were allowed to sell their goods not only in their shops but also on the market-place, every Friday and Saturday.

We know very little about the exact membership of the guilds. But we do know for certain that in the second part of the sixteenth century there were about 60 brewers and more than 80 cheese shops in the city in $1564 .{ }^{25}$ Still we can deduce from the annual number of new members that the guilds of mercers, tailors and stocking makers had considerably more members than those of the brewers, grocers and cheesemongers, which was also the case in other European cities. ${ }^{26}$ In all of these six guilds small businesses were the rule. According to the inquiry into trade and industry in 1738 , mercers, grocers, cheesemongers and tailors had fewer than two journeymen and/or apprentices in their service. ${ }^{27}$ An average of 3.3 workers was usually employed in a stocking maker's workshop and there is nothing to indicate that the situation was different in the sixteenth century. Although we have no exact figures, it may be assumed that the Ghent brewers employed a few more people. ${ }^{28}$

\section{MASTERSHIP: DREAM OR REALITY?}

The European guild system was characterized by a marked hierarchic structure. Most guilds had four social-juridical levels, all having their specific rights and obligations: apprentices, journeymen, masters and board members. The granting of the title of master was considered to be a milestone in the career of a craftsman, as it was not until one was admitted to mastership that one was considered a full member by the guild. Masters distinguished themselves strongly from journeymen in the

hair strings, hats, caps, stockings). Next to the actual mercers, there were four other, smaller groups within the mercers' guild in the early part of the sixteenth century: the bonnet makers, the sheath makers, the knife makers (up till I5II) and the wax candle makers. Only the latter group remained part of the guild after 1540 .

25. De Commer, "De brouwindustrie", 37, pp. I27, I44; series I56 bis, no. 30.

26. C.R. Friedrichs, The Early Modern City, I450-I750 (London and New York, 1995), pp. I46154; idem, Urban Society, pp. 73-94; Rappaport, Worlds, pp. 397-398; D.M. Palliser, Tudor York (Oxford, 1979), pp. I46-I78; R.M. Berger, The Most Necessary Luxuries. The Mercers' Company of Coventry, I550-I680 (Pennsylvania, I993), p. I08; S. Cerutti, "Group Strategies and Trade Strategies: The Turin Tailors' Guild in the Late Seventeenth and Early Eighteenth Centuries”, in S. Woolf (ed.), Domestic Strategies: Work and Family in France and Italy, I600-I800 (Cambridge, 1991), p. I07.

27. Series 156 , no. 3,8 .

28. Antwerp breweries in the sixteenth century employed on average seven to eight journeymen and two to three maids: H. Soly, "De economische betekenis van de Zuidnederlandse brouwindustrie in de I6de eeuw. Problematiek", in Economische geschiedenis van België. Behandeling van de bronnen en problematiek. Handelingen van het Colloquium te Brussel, I7-I9 nov. I97I (Ie-IVe secties) (Brussels, I972), p. II5. In London brewers hired considerably more journeymen than other master craftsmen: Rappaport, Worlds, p. 335. 


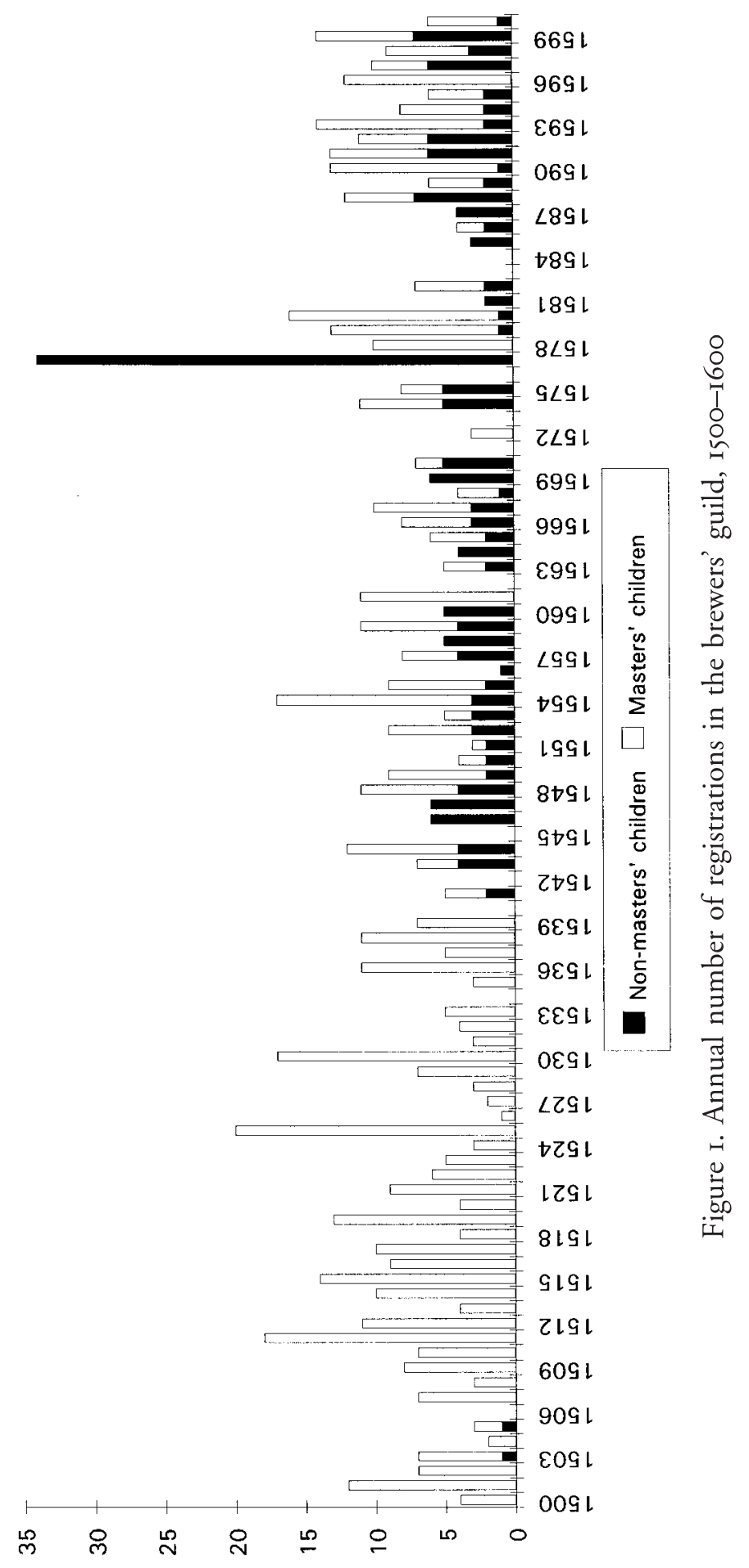




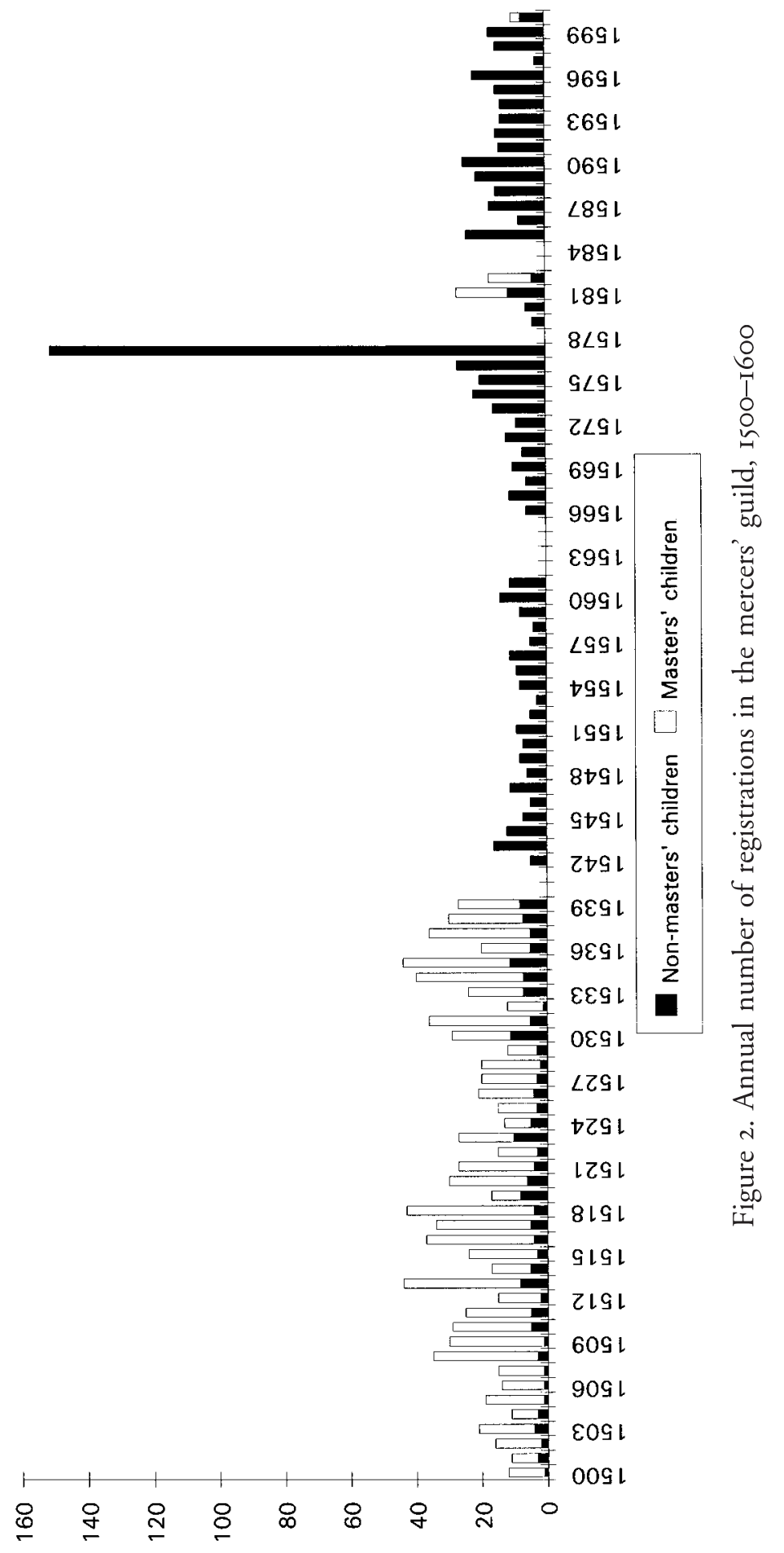




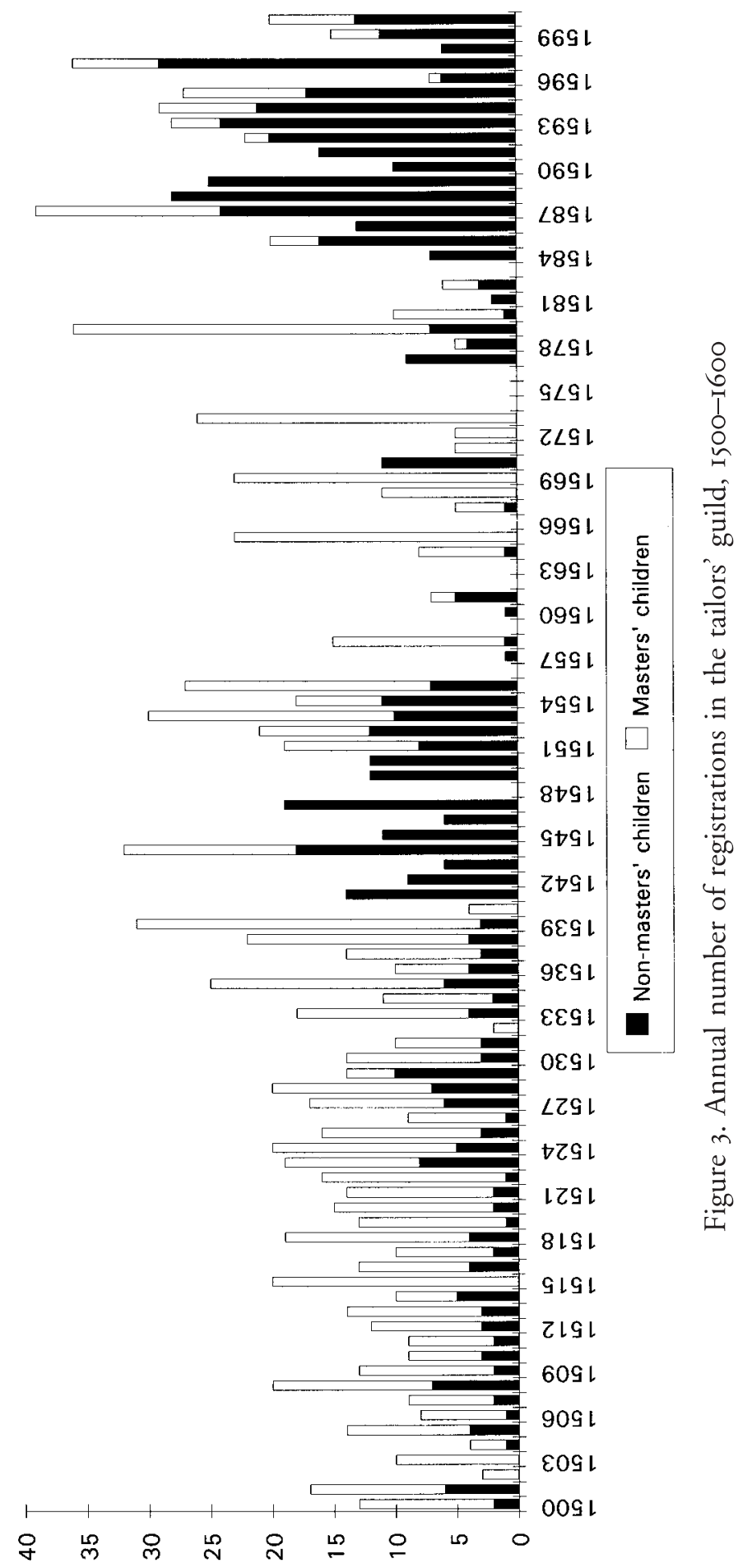




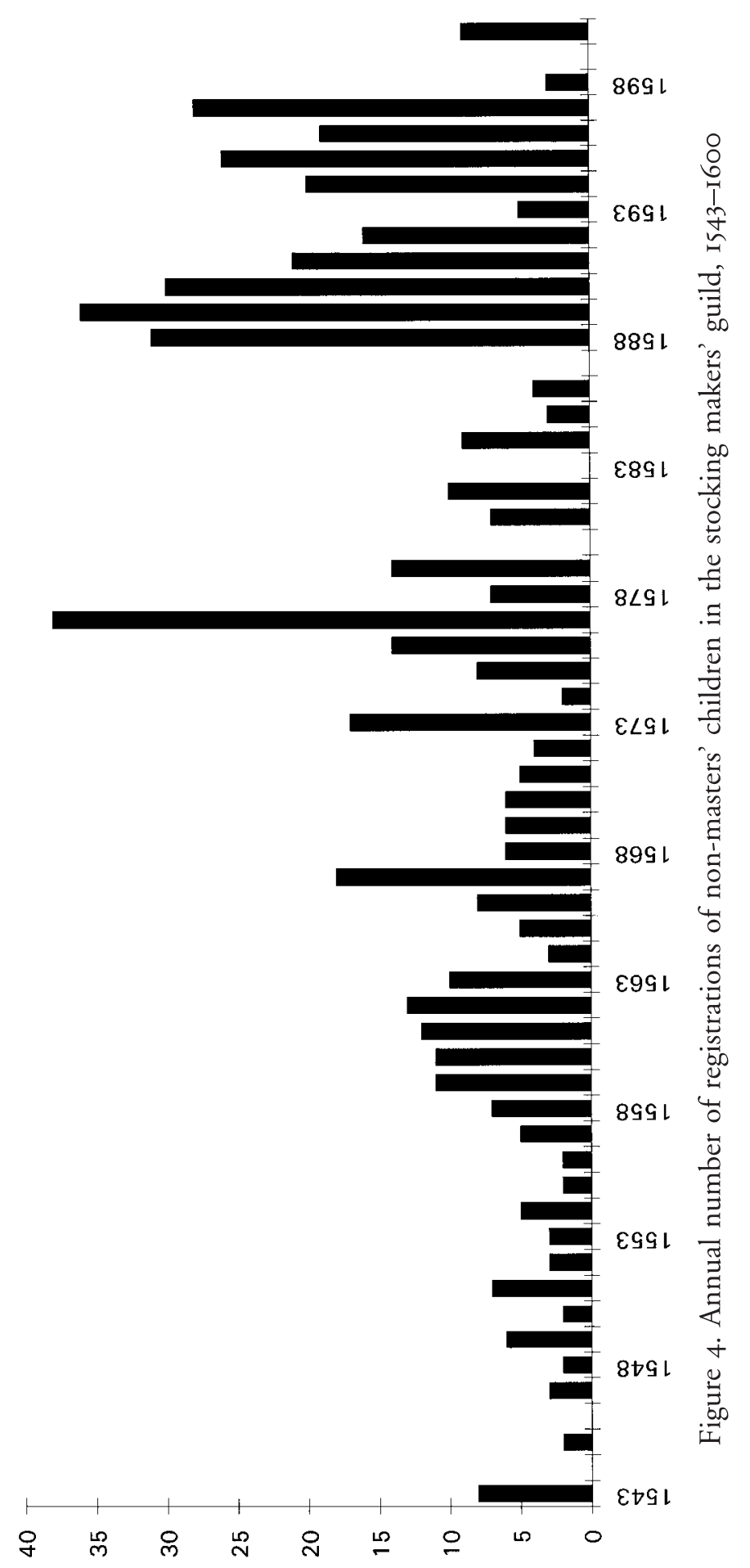




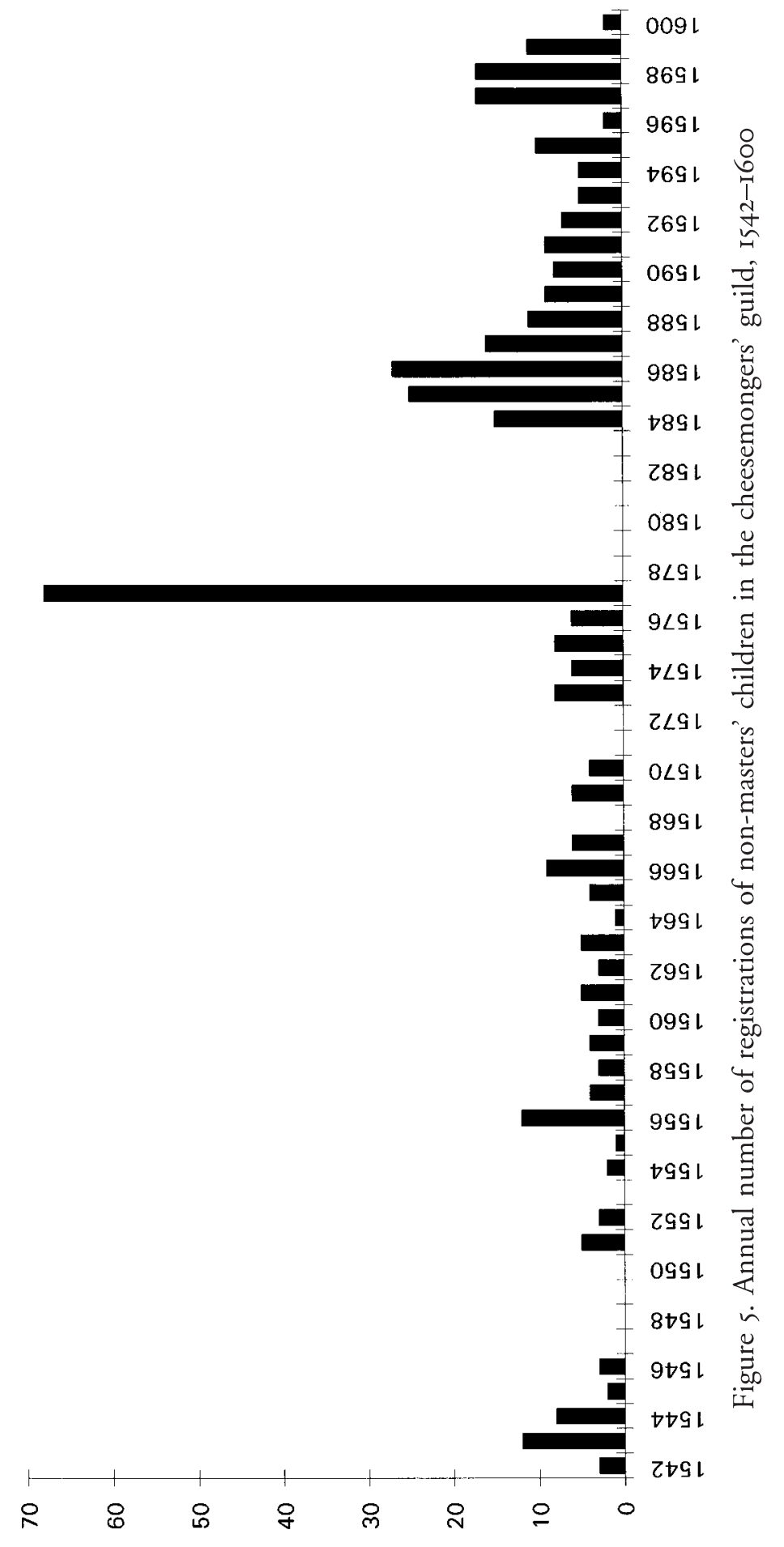




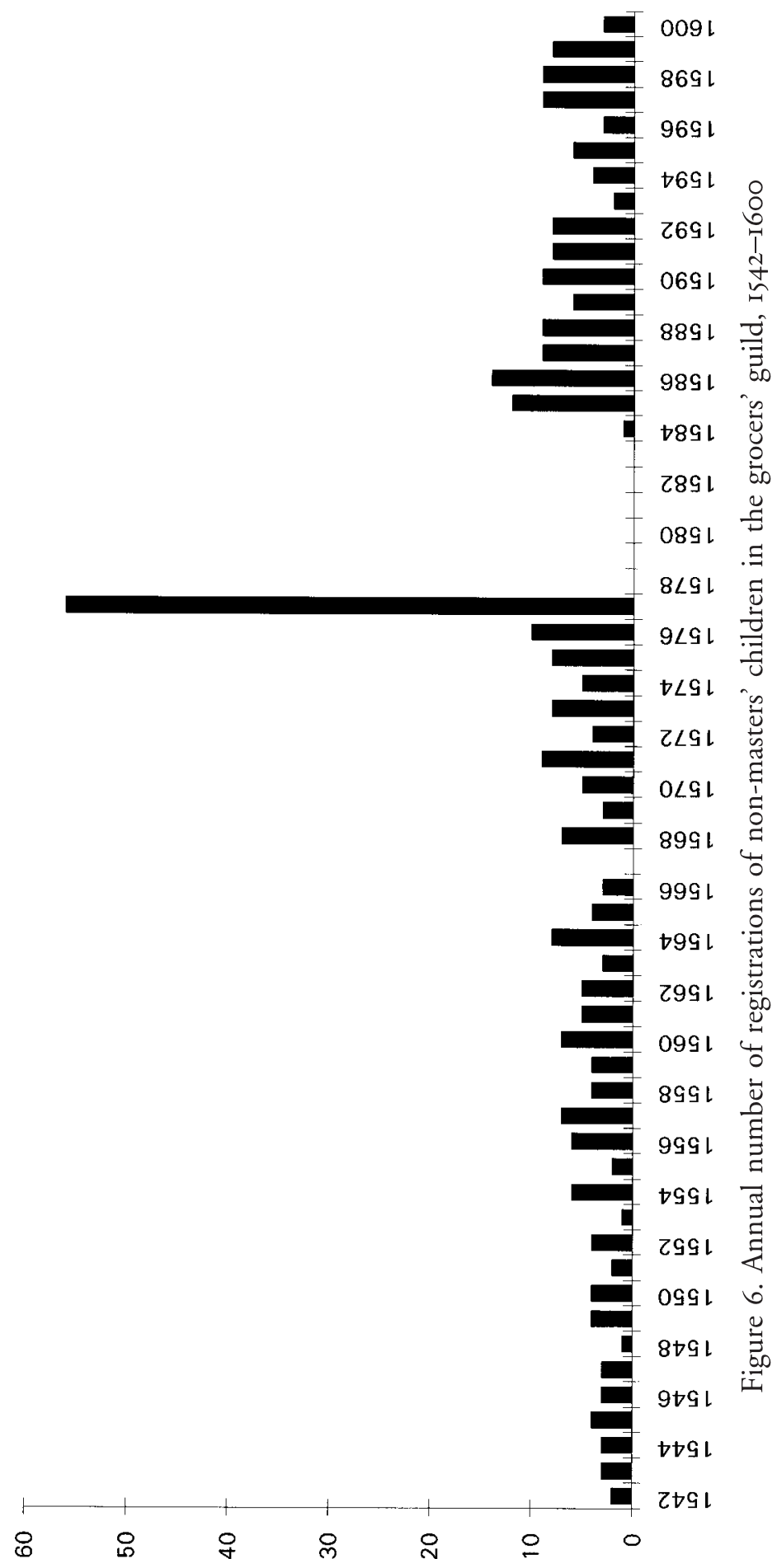


juridical, social-economic and also in the technical fields. ${ }^{29}$ They were the only ones who could run a business and who had a say in running the guild. However, mastership brought with it not only rights, but also obligations. Masters had to observe the guild regulations strictly; they had to attend meetings and ceremonies and make a regular contribution to the funds of the guild.

What criteria had to be met in order to be admitted to mastership in sixteenth-century Ghent? Since the requirements changed several times in the course of that century, a chronological survey is required. As in many Dutch and German cities, the guild mastership in Ghent was inseparable from the burghership (poorterschap) of the city. ${ }^{30}$ Anyone who had been born in the city was juridically considered to be a Ghent burgher. Ghent was very welcoming to immigrants because they could obtain free burghership. Anyone who had been living in the city for a year and a day obtained this burghership automatically. ${ }^{31}$ It was not burghership that constituted an obstacle to becoming a guild member, but the admission fee new masters had to pay to their guild. Before I54O the fee that had to be paid to gain admission to any guild was high, sometimes very high (see Table I). In the mercers' guild roo summer day wages of a journeyman bricklayer were needed to pay this admission fee. But there were substantial differences between the various guilds: for instance, the admission fee for tailors and grocers was about 60 per cent higher than that for mercers, and that for brewers was 220 per cent higher. Paying an entry fee was not the end of the matter, however. Traditionally every candidate for mastership had to present the guild with a silver dish with a gilded edge and embellished with the coat of arms of the guild. This dish had to weigh one mark Troy (244.753 grams) and have a value of 480 gr. $^{32}$ There were also certain

29. In the London guilds a social-juridical dividing line did not really exist between ordinary masters and journeymen, but rather between ordinary masters (householders) and elite masters (liverymen): Rappaport, Worlds, p. 376.

30. In English cities citizenship was linked to apprenticeship: Palliser, Tudor York, p. I47. In French cities, however, one did not need to be a citizen in order to become a master: Friederichs, The Early Modern City, pp. I43-I44.

31. This was regulated by the Great Charter of Count Guy of Dampierre in I297: J. Decavele, "De Gentse poorterij en buitenpoorterij", in Recht en instellingen in de oude Nederlanden tijdens de Middeleeuwen en de Nieuwe Tijd. Liber amicorum Jan Buntinx (Louvain, 198I), pp. 64, 69. Although certain juridical aspects of the inner and outer citizenship led to conflicts between the city and the monarch in the fourteenth and fifteenth centuries, the inner citizenship remained gratis: see M. Boone, "Droit de bourgeoisie et particularisme urbain dans la Flandre bourguignonne et habsbourgeoisie (1384-I585)", Belgisch Tijdschrift voor Filologie en Geschiedenis, 74, 4 (1996), pp. 78-97. In many cities immigrants had to pay a burghership fee. In Antwerp this sum equalled as much as 68 day wages of an unskilled labourer in 1544: A.K.L. Thijs, "Minderheden te Antwerpen (I6de/2oste eeuw)”, in H. Soly and A.K.L. Thijs (eds), Minorities in Western European Cities (Sixteenth-Twentieth Centuries) (Brussels, 1995), p. I9.

32. Series 30I, no. 78 , f. IO3v. 
Table I. Evolution of the entry fee expressed in Flemish groats and summer day wages of journeymen bricklayers, IS25-I600

\begin{tabular}{rrrrrrrrrrrrrr}
\hline Year & \multicolumn{2}{c}{ Brewers } & \multicolumn{2}{c}{ Mercers } & \multicolumn{2}{c}{ Tailors } & \multicolumn{2}{c}{$\begin{array}{c}\text { Stocking } \\
\text { makers }\end{array}$} & \multicolumn{2}{c}{$\begin{array}{c}\text { Cheese- } \\
\text { mongers }\end{array}$} & Grocers \\
& \multicolumn{1}{r}{} & \multicolumn{1}{c}{ gr. } & sum & \multicolumn{1}{c}{ gr. } & sum & gr. & sum & gr. & sum & gr. & sum & gr. & sum \\
\hline 1525 & 3,840 & 320 & 1,200 & 100 & 1,920 & 160 & - & - & - & - & 1,920 & 160 \\
1540 & 240 & 20 & 240 & 20 & 240 & 20 & 240 & 20 & 240 & 20 & 240 & 20 \\
1560 & 240 & 15 & 240 & 15 & 240 & 15 & 240 & 15 & 240 & 15 & 240 & 15 \\
1570 & 240 & 12 & 240 & 12 & 240 & 12 & 240 & 12 & 240 & 12 & 240 & 12 \\
1580 & 11,520 & 320 & - & - & - & - & 1,440 & 40 & - & - & 3,840 & 106 \\
1585 & 240 & 7 & 240 & 7 & 240 & 7 & 240 & 7 & 240 & 7 & 240 & 7 \\
1600 & 240 & 6 & 240 & 6 & 240 & 6 & 240 & 6 & 240 & 6 & 240 & 6 \\
\hline
\end{tabular}

Sources: Entry fees: City Archives of Ghent, series I60, no. 6; series 178, no. I; series I9I, nos I and 2; series 165 , no. 2; series I7I/I, no. I; series I72, nos 3 and 4. Wages: E. Scholliers, "Lonen te Gent (XVe-XIXe eeuw)", in Dokumenten voor de geschiedenis van prijzen en lonen in Vlaanderen en Brabant (XIVe-XIXe eeuw), II (Bruges, I965), pp. 354-46I.

guilds which required a banquet and in addition to that there were small financial obligations such as an allowance for the dean and the jurors. ${ }^{33}$ As far as can be gathered, the candidates for mastership were not subjected to a master test before 1540 .

When we add up the various financial contributions we find that in 1522 the freedom from the mercers' guild cost I,920 gr. in total, which is the equivalent of 160 summer day wages of a journeyman bricklayer. To obtain the title of master tailor, 2,400 gr. or 200 summer day wages were required..$^{34}$ It is clear that many people would never have been able to obtain the master's title without the financial support of another person, even though they were allowed to spread the payment over many years. Family ties and social relations seem to have been of primary importance. Postponement of payment was allowed only if two people were willing to stand surety. In many cases the father of the prospective master was one of these two people, ${ }^{35}$ but other family members committed themselves too. ${ }^{36}$ Sometimes a relative paid the whole amount: Elisabeth Laureyns, for example, bought the freedom from the grocers' guild for her son-in-law Jan du Molyn, for the sum of $3,840 \mathrm{gr}^{37}{ }^{37}$ The mastership contracts that were made for aldermen show that many of the people who stood surety belonged to the world of

33. In the mercers' guild the dean and jurors were entitled to 240 gr.: series 301, no. 78 , f. $68 \mathrm{r}$. 34. Ibid., f. 68r, Io3v.

35. Some examples: in 1522 Michiel Viveraert stood surety for his son Anthonis, who bought the freedom from the mercers' guild: series 30I, no. 78, f. 68r. Lieven Van Canengys did the same for his son Jan, a master grocer, in I523: series 30I, no. 78, f. 256 r.

36. In I519 Jan Van den Hecke stood surety for his son-in-law, Jooris Fiers, a grocer: series 30I, no. 76, f. I2v. Cornelis Blommaert did the same for his brother Arendt, a mercer, in 1522: series 30I, no. 78 , f. $68 \mathrm{r}$.

37. Series $30 \mathrm{I}$, no. I25, f. 4 Ov. 
the guilds. ${ }^{38}$ The examples mentioned clearly illustrate that it was well nigh impossible, without the necessary help and relationships, to obtain the title of master during the first four decades of the sixteenth century. It may be assumed that the circle of acquaintances of a prospective master was determined in the first place by his social background. That is why we believe that those who were admitted to mastership in the years I50O-I540 were mostly people from the social world of master craftsmen or from a social background more or less equivalent to that of master craftsmen.

But the year 1540 brought a change. By promulgating article 73 of the Concessio Carolina, Charles V intended to make it easier for outsiders to gain access to mastership and to put a stop to the tendency towards corporative heredity. ${ }^{39}$ By enacting this article he hoped to be able to contribute to the economic revival of his native city. The emperor started from the principle that a prospective master had to be able to prove his technical skills rather than have a heavy purse. Therefore one had to take a test in order to be awarded the master's title, and the admission fee that had to be paid was a non-recurrent and uniform amount of 240 gr. $^{40}$ Twenty summer day wages of a journeyman bricklayer were enough now to pay the admission fee. ${ }^{41}$ In the light of the substantial increases in prices and wages in the sixteenth century, it is striking that this entry fee was not increased until Calvinist rule. On the contrary, in real terms the amount even decreased: in 1570 the fee was equivalent to I2 summer day wages. It is clear, therefore, that both the central and the local authorities deliberately kept the admission fee so low. In view of the nature of their activities, mercers, grocers and cheesemongers were not subjected to a test to obtain the title of master, not even after 1540. ${ }^{42}$ For the other three craft guilds a master test was introduced, but there is not one sixteenth-century document providing information on

38. In 1520 master pewterer Ancelmus De Cop stood surety for Jan Blomme, a mercer, and in I523 master carpenter Anthonis Van Conyncdonc stood surety for Lievin Walravins, a tailor: series 30I, no. 76 , f. $28 \mathrm{v}$; no. 78 , v. $22 \mathrm{Ir}$.

39. J. Lameere and H. Simont, Recueil des Ordonnances des Pays-Bas, series 2, IV (Brussels, I907), p. I88.

40. In contrast to, for example, the cities of the Upper and Central Rhine area, where the master test was universalized only in the sixteenth century, the introduction of the test in Ghent was not intended as an obstacle to admission to a guild: K. Schulz, Handwerksgesellen und Lohnarbeiter. Untersuchungen zur oberheinischen und oberdeutschen Stadtgeschichte des I4. bis I7. Jahrhunderts (Sigmaringen, I985), p. 3II.

4I. By way of comparison: in the Bruges shoemakers' guild, which was not considered to be a guild of high social esteem, a candidate for mastership had to pay 720 gr. in the sixteenth century and a candidate who had learned the trade outside the city had to pay I,200 gr.: Van Quathem, "Sociale mobiliteit", p. II5. In I5I5 the admission fee of the Antwerp carpenters' guild was fixed at 600 gr.: Scholliers and Vandenbroeke, "Structuren en conjuncturen", p. 303.

42. Series 156 , no. 7 . 
the exact nature of these tests. Only in 1599 did the city council order that the master tests were to be described clearly. ${ }^{43}$

One result of the application of the Concessio Carolina was that from that moment on the guilds had two juridical categories of masters: those with a hereditary title and those with a personal title. For the Concessio Carolina prescribed that henceforth all new masters could buy the title of master only for themselves; it was no longer possible to pass the title on to their descendants. However, families who had bought freedom before 1540 kept this privilege.

The Calvinist period (1577-1584) involved a return to the politicalinstitutional and social order of before the Concessio Carolina. The fact that the regime of the three members was restored also meant that the high entry fees from before 1540 were reintroduced. The admission fee for stocking makers was increased to I, 440 gr., for grocers it was increased to 3,840 gr. and for brewers it rose to the astronomic amount of II,52O gr. ${ }^{44}$ But it would be wrong to conclude that by asking such high admission fees the guilds closed their doors to outsiders. These high sums were justified because they related to hereditary mastership. In real terms a candidate for mastership in the brewers' guild paid the same amount as before 1540 , but a candidate for mastership in the grocers' guild paid 34 per cent less. By abolishing personal mastership, uniformity again had to make way for diversity: the admission fee that had to be paid by grocers was 2.7 times higher than the fee required of stocking makers, and the entry fee to be paid by brewers was as much as 8 times higher. The custom of the silver dish was also re-established, ${ }^{45}$ and in many guilds a banquet was required again. ${ }^{46}$ In addition to all that, an extra sum had to be paid by brewers, tailors and stocking makers for the costs of the master test. When we add everything up, we can only conclude that a substantial sum had to be paid. Adriaen Van der Stichele, a grocer, paid a total of 5,040 gr. in 1584 , which is the equivalent of I4O summer day wages. But Rachen De Meyere, a brewer, beat the lot in 1582: he paid 13,440 gr. or 373 summer day wages ${ }^{47}$ Even Jan Van

43. Series I77, no. I, f. 56r. In the seventeenth century the master test of the tailors consisted of making a priest's garb and a cymar (a long woman's gown) and the test of the stocking makers consisted of making three pairs of stockings: Minard-Van Hoorebeke, Description, pp. I33, I35.

44. Series 30I, no. I27, f. 42r; series 30I, no. I26, f. I04r. A journeyman who had learned the trade outside the town had to pay I,920 gr.: series 165 , no. 9 , f. $2 \mathrm{v}$.

45. For a silver dish the aspirant paid 720 gr.: series 30I, no. I27, f. $42 \mathrm{r}$.

46. In 158I Franchois Hoobrouc offered the dean and the jurors of the brewers' guild a meal worth I,200 gr. A year later brewer Rachen De Meyere paid I,440 gr.: series 30I, no. I26, f. 67r, I04r. The banquets of the grocers were more modest: the meal that candidate Adriaen Van der Stichele offered to the board in 1584 cost 480 gr.: series 301 , no. I27, f. 42 r. The rules of the stocking makers' guild in 1579 also mention an obligatory meal: series 165 , no. 9, f. $2 \mathrm{v}$.

47. Series 30I, no. I27, f. 42 r; no. I26, f. 67 r. 
Hembyze, mayor and strong man of the Calvinist republic, was of the opinion that the admission fees were soaring and in 1579 he therefore asked the deans whether they would be willing to open their guilds to Protestant immigrants for three or four years. He proposed an entry fee of 240 to 360 gr., but the deans did not comply with his request. ${ }^{48}$ That the fees constituted a considerable obstacle and that many candidates for mastership could not afford those high amounts is also proved by the fact that only ten of the twenty-three registered stocking makers obtained the title of master in $1582-1583$. One year later none of the nine registered candidates was able to obtain freedom. ${ }^{49}$

After the retrocession of the city to the Spanish King Philip II (I7 September 1584) the stipulations of the Concessio Carolina became effective again. By way of a transitional measure the city council decided in January I585 that those who had bought hereditary mastership during the Calvinist period would be allowed to retain this privilege and those who had started to pay off this hereditary mastership but who had problems in paying the entire sum were to obtain personal mastership, whereas those who still wanted to obtain hereditary mastership were to observe the contract they had entered into with the guild during the Calvinist period. ${ }^{50}$

So far we have only discussed non-masters' children. The sixteenthcentury sources of information are (deliberately?) very vague about the conditions of admission for masters' children. In fact masters' children obtained the title of master the moment they were born. Yet they had to have this title registered to make it valid and that is the reason masters' children were entered in the membership records at a very young age. According to the fourteenth-century statutes of the mercers' guild every master's child could join the guild by paying the sum of 5 gr. and by giving the board a jug of wine. In the by-laws of the brewers' guild of 1453 it was stipulated that the admission fee for masters' children was Io gr. And according to the regulations of 1579 every stocking maker who had his children entered in the

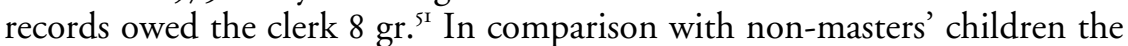
admission fee to be paid by heirs was just a flea-bite. In addition, masters' children were not subjected to a test to join the guild. To be able to inherit the master's title the children had to be born after their father had bought his title of master..$^{52}$ As for brewers, mercers and tailors, the title of master

48. B. De Jonghe, Ghendtsche geschiedenissen of chronyke van de beroerten en ketterye binnen, en ontrent de stadt van Ghent seder 't jaer 1566 tot het jaer 1585 (Ghent, 1752), 2, p. I38.

49. Item alle dees naervolghende persoonnen en sijn niet vrij als niet betalt hebbende: series 165 , no. 2, f. I6r, I8r.

50. Series I07, no. 4, f. $3 \mathrm{v}$.

5I. E. Van der Hallen, "Het Gentse meerseniersambacht (1305-I540)", Handelingen der Maatschappij voor Geschiedenis en Oudheidkunde te Gent, 3I (1977), p. Io6; series I60, no. 6, f. 9r-v. If the children of a stocking maker died before their registration, the father had to pay the clerk of the guild 4 gr.: series 165 , no. 9 , f. 2 r.

52. Series I60, no. 6, f. 9v. In France too this was the rule: Coornaert, Les corporations, p. I97. 
was automatically passed on to bastard children too. ${ }^{53}$ It cannot be denied, therefore, that masters' children and non-masters' children were not treated equally before 1540. The Concessio Carolina did not affect the privileged statute of masters' children. Still the financial gap between masters' children and non-masters' children did become smaller, thanks to the fact that the entry fee for outsiders was decreased. But it was only in the seventeenth century that the juridical difference between both groups was eliminated..$^{54}$

To what extent did the conditions of admission we have just discussed determine admittance to the various guilds? Table 2 shows that only the brewers' guild had evolved into a closed and hereditary occupational association in the late Middle Ages: between I500-I540 there were only two brewers who bought the freedom. 55 The closed character of the brewers' guild can be explained by the specificity of this sector. This branch of industry was characterized by a high degree of capital intensity, low labour intensity and high productivity. ${ }^{56}$ The fact that the brewers were permanently represented on the city council also explains why their position was not affected before 1540. In the mercers' guild an average of 4.5 outsiders per year bought the freedom between 1500-1540; in the tailors' guild this average was no higher than 3.I. The lower entry fee and the greater chance of employment in comparison with the brewers explains the relatively high number of registrations of non-masters' children in the two guilds. Consequently it would seem that the Ghent guilds were less closed than was formerly believed. Moreover, the mastership contracts in the aldermen's registers show that the financial obstacle was not as great as it seemed at first sight, because the money did not have to be paid at once.

That the drastic interference of Charles V in the Ghent guild system bore fruit is clearly and undeniably shown by Table 2. In all guilds there was a spectacular increase in the number of newcomers: between I540-1577 tailors had 2.7 times and mercers 3.2 times as many purchasers as in the previous forty years. The brewers' guild was going through a real revolutionary period: the annual mean number of non-masters' children increased from O.I to 4.3 ! In spite of the strong increase in the number of new master brewers in proportional terms, in absolute terms the brewers' guild remained the most closed of the six guilds after 1540. For only the conditions of admittance changed, not the specificity of the economic sector. In the short

53. In the brewers' register sixteen bastards are registered, in the mercers' register seven and in the tailors' registers one.

54. On 7 April 1636 the municipality promulgated an ordinance which also obliged masters' children to pay an entry fee of 240 gr.: series 93 , register VV, f. $78 \mathrm{v}$.

55. On 24 August 1503 Jan De Keysere obtained the mastership of the brewers' guild and Joes Van Reynscoet obtained it on 2 December I504: series I6o, no. 6, f. 78, 79r.

56. H. Soly, "Nijverheid en kapitalisme te Antwerpen in de i6e eeuw", in Album Charles Verlinden (Ghent, 1975), p. 345. Rappaport also points out the limited opportunities for social mobility within the brewers' company in sixteenth-century London: Rappaport, Worlds, p. 335. 
Table 2. Annual mean number of registrations of masters' children and nonmasters' children for the four political periods, I500-I600

\begin{tabular}{|c|c|c|c|c|c|c|c|c|c|c|c|c|}
\hline & \multicolumn{2}{|c|}{ Brewers } & \multicolumn{2}{|c|}{ Mercers } & \multicolumn{2}{|c|}{ Tailors } & \multicolumn{2}{|c|}{$\begin{array}{l}\text { Stocking } \\
\text { makers }\end{array}$} & \multicolumn{2}{|c|}{$\begin{array}{l}\text { Cheese- } \\
\text { mongers }\end{array}$} & \multicolumn{2}{|c|}{ Grocers } \\
\hline & Mas. & Non & Mas. & Non & Mas. & Non & Mas. & Non & Mas. & Non & Mas. & Non \\
\hline $1500-1540$ & 7.3 & 0.1 & 19.7 & 4.5 & 10.5 & 3.1 & - & - & - & - & - & - \\
\hline $1540-1577$ & 4.9 & 4.3 & - & 14.4 & 12.6 & 8.4 & - & 7.7 & - & 6.4 & 6.3 & 6.1 \\
\hline $1578-1584$ & 10.5 & 1.2 & 14.5 & 6.3 & 10.5 & 3.4 & - & 7.6 & - & - & - & - \\
\hline $1584-1600$ & 5.7 & 3.4 & - & 15.3 & 6.2 & 16.8 & - & 17.3 & - & 11.5 & - & 7.1 \\
\hline
\end{tabular}

Sources: See Table I.

Note: The annual mean for non-masters' children in the tailors' guild between I540-I577 is a minimum, since only incomplete figures or no figures at all are available for quite a number of years.

term the effects of the Concessio Carolina were most noticeable in those guilds that used to demand the highest admission fees: the annual mean number of master purchasers in the brewers' guild increased from 0 in the decade $1530-1539$ to 3.5 during the next ten years; in the tailors' guild this number increased from 3.2 to I0.6, whereas in the mercers' guild there was only a slight increase: from 6.7 to 7.8 . Between 1540 and 1577 there was an upward trend in all the guilds. In the brewers' guild the annual mean during the I570s was twice as high as that during the 1540s, and in the cheesemongers' guild it was almost three times that figure. In the mercers' and stocking makers' guilds the number had almost increased fourfold and in the grocers' guild it had increased fivefold. This high number of new registrations in the I570s has to do not only with the decrease in the admission fee (in real terms) and the revival of Ghent's economic fortunes, but also the massive purchase of freedom in the year 1577 (see Figures I, 2, 4, 5 and 6). The municipal ordinance of 4 November 1577 was the cause of this enormous peak in all the guilds. ${ }^{57}$ Before returning to hereditary mastership the Ghent city council offered the citizens the opportunity, during a period of fourteen days, to buy the personal freedom from any guild, with the exception of the three hereditary guilds (bargees, butchers and fishmongers). They could buy this freedom at the old rate of 240 gr. The conditions were that one had to be a burgher, at least sixteen years old and willing to take the master test. Since they feared a future increase in entry fees, many townsmen bought the master's title from a guild. In the mercers' guild the number of buyers increased sixfold in comparison with 1576 , in the grocers' guild there was a fivefold increase and in the cheesemongers' guild the number increased elevenfold. Most buyers did not have a relative in the guild..$^{58}$

57. Series 93, no. 29 (register EE), f. I66r. See also series I07, no. 3, f. I55V.

58. Among the brewers and mercers in 1577,62 per cent of purchasers had a surname that did not hitherto occur among the guild members, among the stocking makers this was 63 per cent, 
Table 3. Proportion of non-masters' children to masters' children for the four political periods, I500-I60o (\%)

\begin{tabular}{lcccccccc}
\hline \multirow{2}{*}{ Period } & \multicolumn{2}{c}{ Brewers } & \multicolumn{2}{c}{ Mercers } & \multicolumn{2}{c}{ Tailors } & \multicolumn{2}{c}{ Grocers } \\
& non & mas. & non & mas. & non & mas. & non & mas. \\
\hline $1500-1540$ & 0.7 & 99.3 & 18.5 & 81.5 & 23.0 & 77.0 & - & - \\
$1540-1577$ & 46.4 & 53.6 & - & - & 40.1 & 59.9 & 49.0 & 51.0 \\
$1578-1584$ & 10.3 & 89.7 & 30.1 & 69.9 & 24.5 & 75.5 & - & - \\
$1584-1600$ & 37.2 & 62.8 & - & - & 73.1 & 26.9 & - & - \\
\hline
\end{tabular}

Sources: See Table I.

Note: In order to solve the problem of missing years, the above percentages were calculated on the basis of the annual average number of registrations per political period.

As a result of the high entry fees the number of master purchasers decreased drastically in most guilds during the Calvinist period. Only the stocking makers were, surprisingly, able to maintain their level of master purchasers. After the reconciliation the number of registrations reached a peak. As a proportion of the entire working population, the number of new masters in the sixteenth century had never before been so high. This high number was undoubtedly connected with the demographic decline Ghent had to face after the retrocession to Philip II. After I 584 some 20 to 25 per cent of the population emigrated to a foreign country (Germany, England and especially the Dutch Republic) for religious, political and economic reasons. ${ }^{99}$ There were very many master craftsmen among those emigrants and this exodus resulted in a lack of skilled craftsmen on the labour market. To many young people this was an ideal opportunity to move up on the social ladder. This social rise was also stimulated by the low price of admission: 6 summer day wages was sufficient to join a guild!

The proportion of non-masters' children to masters' children changed drastically in the course of the sixteenth century (Table 3). On the basis of the number of entries in the registers it may be stated that until 1540 masters' children had a substantial numerical preponderance over non-masters' children in all the guilds that were investigated. Yet the entries of masters' children must be put into perspective, since we may assume, by analogy with the situation in other cities, that only a minority of those children actually practised the trade. ${ }^{60}$ It is a fact that after 1540 the number of

among the grocers 64 per cent, and among the cheesemongers the figure was as high as 82 per cent.

59. J. Dambruyne, "De Gentse immobiliënmarkt en de economische trend, I590-1640", Bijdragen en Mededelingen betreffende de Geschiedenis der Nederlanden, I04 (1989), p. I62.

6o. Several studies have shown that up to a quarter of masters' children followed in their father's footsteps: S. Cerutti, "Du corps au métiers: la corporation des tailleurs à Turin entre le XVIIe et le XVIIIe siècle”, Annales ESC, 43 (1988), p. 326; P. Guignet, "Structures corporatives et mécanismes de reproduction sociale: l'exemple des mulquiniers Valenciennois au XVIIIe siècle”, in Actes du colloque "La sociabilité urbaine en Europe de Nord-Ouest du XIVe au XVIIIe siècle" (Douai, I983), pp. II2-II4; Van Quathem, "Sociale mobiliteit", p. IIO. 
Table 4. Double membership, $1584-1600$

\begin{tabular}{lcccc}
\hline & Tailors & Stocking makers & Grocers & Cheesemongers \\
\hline Total number of new masters & 286 & 260 & 121 & 196 \\
$\begin{array}{l}\text { No. of masters with double } \\
\text { membership }\end{array}$ & 108 & 108 & 52 & 52 \\
Percentage & 37.8 & 41.5 & 43.0 & 26.5 \\
\hline
\end{tabular}

Sources: City Archives of Ghent, series I9I, no. 2; series I65, no. 2; series I7I/I, no. I; series I72, nos 3 and 4 .

Note: Missing years for the stocking makers: 1587, 1599. The figures cover only masters who bought the freedom of both guilds after August I584.

masters' children decreased considerably in all guilds. The installation of the Calvinist republic put a stop to this trend. Again there were many more entries of masters' children in all guilds than there were entries of outsiders, but their preponderance was short-lived since after 1584 most new members came from the group of non-masters' children.

The Ghent citizens were free to join more than one guild. Although there are no exact figures available, it seems that the phenomenon of double membership occurred fairly often in certain Ghent guilds in the sixteenth century. It is fairly obvious that it occurred most of all in guilds which were active in the same economic sector. This double membership is seen most often among tailors, stocking makers, grocers and cheesemongers. ${ }^{61}$ The source material available for the years $1584-$ I600 allowed us to calculate the occurrence of dual mastership (see Table 4). The high percentages indicate a strong occupational connection between tailors and stocking makers on the one hand and between grocers and cheesemongers on the other. We believe that the high percentage of double memberships can be explained in the first place by the low admission fees. It is striking how short the period of time was between the acquisition of mastership in the two guilds: 73 per cent of the tailors and stocking makers and 86 per cent of the grocers and cheesemongers bought the freedom from the second guild within a period of two years. This double membership cannot be seen as a form of intragenerational occupational mobility since craftsmen did not give up their original occupation; they simply combined it with a second occupation which, in most cases, was in line with their first one.

European guilds were mostly male organizations, and that was also the case in sixteenth-century Ghent. Women were considered to be

6I. In spite of the many lacunae in the source material we have been able to identify some 70 masters, for the period I500-1584, who were both a member of the tailors' and of the stocking makers' guild. For the period between 1540 and 1584 we came across 24 cases of double membership among grocers and cheesemongers. In France, too, double membership was not uncommon: Coornaert, Les corporations, pp. II4, 207; Shephard, "Social and Geographic", pp. II4-II5. 
Table 5. Comparison between the number of male and female masters who bought the freedom of the guild, I500-I600

\begin{tabular}{lrccrrrrrrrrrr}
\hline & \multicolumn{2}{c}{ Brewers } & \multicolumn{2}{c}{ Mercers } & \multicolumn{2}{c}{ Tailors } & \multicolumn{2}{c}{ Stocking } & \multicolumn{2}{c}{ Cheese- } & \multicolumn{2}{c}{ Grocers } \\
& \multicolumn{1}{c}{ no. } & \multicolumn{1}{c}{$\%$} & \multicolumn{1}{c}{ no. } & $\%$ & no. & $\%$ & no. & $\%$ & no. & $\%$ & no. & $\%$ \\
\hline Men & 194 & 100.0 & 790 & 86.8 & 608 & 98.5 & 547 & 99.1 & 337 & 84.3 & 299 & 89.3 \\
Women & 0 & 0.0 & 120 & 13.2 & 9 & 1.5 & 5 & 0.9 & 63 & 15.8 & 36 & 10.7 \\
Total & 194 & 100.0 & 910 & 100.0 & 617 & 100.0 & 552 & 100.0 & 400 & 100.0 & 335 & 100.0 \\
\hline
\end{tabular}

Sources: City Archives of Ghent, series I60, no. 6; series I78, no. I; series I9I, nos I and 2; series I65, no. 2; series I7I/I, no. I; series 172 , nos 3 and 4 .

second-class members: ${ }^{62}$ they were not admitted to the plenary meetings of the masters and they could not claim a seat on the guild board. Their position in the guilds cannot be detached from the sex roles in pre-industrial society. A woman's most important tasks were the education of her children and attending to the household. Highly skilled labour and heavy work was reserved exclusively for men. Yet women played an important role behind the scenes and many helped their husbands in their shops.

Table 5 shows that the various guilds adopted a different attitude with regard to women. In the brewers' guild women - whether married or not were not allowed to practise the trade. But an exception was made for the widows of hereditary masters. As long as they did not remarry, they were allowed to continue running the business of their deceased husband. ${ }^{63}$ This restriction was meant to protect one's own social group. It was feared that by marrying a master's widow outsiders would be able to make a quick social promotion and build up a secure future, which might constitute a threat to other established masters. Although in the tailors' and stocking makers' guild women were admitted to mastership, their number was negligible. However, the guilds of cheesemongers, grocers and mercers did admit women (both masters' daughters and outsiders) and their presence in these guilds can largely be explained by the fact that there were no specific requirements for practising these occupational activities. It was a custom in these trade guilds that anyone marrying a master's daughter or a master's widow only had to pay half the normal admission fee to be allowed to join the

62. See M.E. Wiesner, Working Women in Renaissance Germany (New Brunswick, I986); M.E. Wiesner, "Guilds, Male Bonding and Women's Work in Early Modern Germany", Gender and History, I (1989), pp. I25-I37; M. Wiesner-Hanks, "A Learned Task and Given to Men Alone': The Gendering of Tasks in Early Modern German Cities”, Journal of Medieval and Renaissance Studies, 25 (Winter, 1995), pp. 89-I06; Friedrichs, The Early Modern City, pp. I55, I6I, I63.

63. Series I6o, no. 6, f. $95 \mathrm{v}$. 
guild, ${ }^{64}$ but even in the guilds which were more kindly disposed towards women, only II to 16 per cent of the non-masters' children were women. ${ }^{65}$

\section{THE WAY TO THE TOP: THE GUILD ELITE}

Social mobility within the guilds did not stop at the acquisition of the title of master. Ambitious masters did not content themselves with their title, but strived for a position on the board. The most important attraction of a position on the board was not really the financial or material rewards, but rather the honour and prestige conferred on the holder of such an office. Holding a position on the guild board was the most appropriate way for a master to move up on the social ladder. The special costume worn during ceremonies and processions made board members contrast sharply with ordinary craftsmen. ${ }^{66}$ The most important positions on the board were those of dean (deken) and of juror (gezworene). ${ }^{67}$ The dean was the first in rank among the jurors and he had political power. Since the Peace of Cadzand (I492) the city council elected the dean from among three candidates nominated by the guild. The guilds chose their jurors autonomously. The office of dean was abolished in I540 by Charles V for political reasons and replaced by the office of headman (overste or hoofdman). ${ }^{68}$ From that moment on the jurors were chosen by the headman and by the jurors who had held office during the previous two years. The office of dean was reintroduced during the Calvinist period.

With a view to our prosopographic inquiry into the board elite we analysed a total of 1,633 mandates of deans and jurors. Table 6 shows that less than a quarter of all master craftsmen managed to get a position on the board, and that was also the case in other cities and during other periods. ${ }^{69}$ Still there was an enormous difference in the degree of participation in the various guilds. The highest degree of master participation was found in the

64. M. Danneel, Weduwen en wezen in het laat-middeleeuwse Gent (Louvain and Apeldoorn, 1995), p. 355 . See, for example, series 30I, no. 76, f. I2v.

65. Among the masters' children female heirs were also in the minority. The mercers' guild, for example, had 26.7 per cent masters' daughters.

66. In contrast with sixteenth-century London the social distinction between masters who were members of the board and those who were never admitted to the guild board was never institutionalized in Ghent. Within the London guilds there was a formal juridical distinction between householders and liverymen. Only the latter group could become members of the guild board: Rappaport, Worlds, pp. 244-26o. Concerning the sense of honour among artisans see J.R. Farr, Hands of Honor, Artisans and Their World in Dijon, I550-1650 (Ithaca and London, 1988).

67. In this article we have disregarded lesser functions such as controller of the master tests (proefmeester), manager of the real estate of the guild (huismeester) and inspector (waardeerder).

68. Because the headmen were not recruited from among the masters, we shall disregard them in this article.

69. In the shoemakers' guild in Bruges only 23 per cent of masters held a board mandate during the period 1570-1794: Van Quathem, "Sociale mobiliteit", p. I27. 
Table 6. Number and percentage of masters and families holding a board mandate (deans and jurors), I500-I600

\begin{tabular}{lcccccc}
\hline & Brewers & Mercers & Tailors & $\begin{array}{c}\text { Stocking } \\
\text { makers }\end{array}$ & $\begin{array}{c}\text { Cheese- } \\
\text { mongers }\end{array}$ & Grocers \\
\hline Board members & 205 & 194 & 202 & 68 & 57 & 64 \\
Total no. of masters & 861 & 1,950 & 1,473 & 648 & 436 & 397 \\
Percentage & 23.8 & 9.9 & 13.7 & 10.5 & 13.1 & 16.1 \\
Board families & 74 & 126 & 121 & 49 & 45 & 44 \\
Total no. of families & 199 & 671 & 524 & 429 & 303 & 255 \\
Percentage & 37.2 & 18.8 & 23.1 & 11.4 & 14.9 & 17.3 \\
\hline
\end{tabular}

Sources: See Table 5.

Note: The figures for the brewers, mercers and tailors cover the period $1500-1600$, those for the stocking makers, cheesemongers and grocers cover the periods I543-I600, I540-I600 and I54II600 respectively.

brewers' guild (23.8 per cent) and the lowest degree of participation was found in the mercers' guild (9.9 per cent) and in the stocking makers' guild (IO.5 per cent). This seems logical because a master of a guild with few members is statistically much more likely to get a position on the board than a master of a large guild. The largest guilds are therefore the less democratic ones. With regard to the number of board families in all guilds but one less than a quarter ever managed to get a seat on the board. We must point out, however, that the percentages for brewers, mercers and tailors relate to the entire sixteenth century whereas those of the other three guilds relate only to the period $1540-1600$. That is why the percentages for the first three guilds are higher. If we consider only the period after 1540 for those guilds too, the percentage for the brewers is 26.I per cent instead of 37.2 per cent and that for the tailors is 9.3 per cent instead of 23.I per cent. These lower percentages can be explained by the fact that after 1540 the guilds had only two jurors and no dean, irrespective of their number of members. In this case too we come to the same conclusion: the fewer the number of families in a guild, the greater were their chances of becoming a member of the board. ${ }^{70}$

The easiest way to get an idea of the degree of monopolization within the guild board is to divide the number of seats available by the number of board members: in other words, to calculate the average number of seats per board member. In order to make a comparison between the six guilds and to see how the average changed over a certain period of time, we made

70. See also the Ghent guild of bricklayers and stonemasons. In the seventeenth century 52 per cent of a total of Ior families of bricklayers and stonemasons were members of the board. In the eighteenth century 55 per cent of a total of 62 families were board members: J. Dambruyne, "De Gentse bouwvakambachten in sociaal-economisch perspectief (1540-1795)", in C. Lis and H. Soly (eds), Werken volgens de regels. Ambachten in Brabant en Vlaanderen, I500-I800 (Brussels, 1994), pp. $77-78$. 
Table 7. Average number of mandates per master and family + participation index of the masters in the guild board, I500-1540

\begin{tabular}{lccc}
\hline & Brewers & Mercers & Tailors \\
\hline Number of mandates* & 288 & 240 & 329 \\
Number of mandataries & 133 & 123 & 148 \\
Average no. of mandates per master & 2.2 & 2.0 & 2.2 \\
Number of board families & 51 & 91 & 97 \\
Average no. of mandates per family & 5.6 & 2.6 & 3.4 \\
Participation index & 46 & 51 & 45 \\
\hline
\end{tabular}

Sources: City Archives of Ghent, series I60, no. 6; series I78, no. I; series I9I, no. I.

Note: *Number of mandates for which we know the name of the mandataries.

Participation index $=\underline{\text { number of mandataries } \times \text { IoO }}$

number of mandates

The participation index varies between I and Ioo.

a distinction between the period before and the period after the Concessio Carolina. Between 1500 and 1540 the average number of mandates per board member was very low in the three guilds (Table 7). This low figure indicates a particularly high mutation pattern within the guild boards and this rotation system was an effective device against the abuse of power. The average number of mandates per family shows that there were substantial differences between the three guilds: in the brewers' guild a board family held twice as many offices as in the mercers' guild. Of course this can be explained by the smaller number of families and the greater occupational continuity within the brewers' guild.

However, these average figures do not allow us to form an exact picture of the democratic or oligarchic character of the guild boards. We must also take into account the total number of members and especially the number of offices available as well as the duration of those offices. Before 1540 and also during the Calvinist period the number of board members per guild was widely divergent. ${ }^{71}$ To avoid positions on the board becoming hereditary, the duration of those offices was restricted by the statutes of the guilds. ${ }^{72}$ Since the various guild boards all had a different number of members, we constructed a participation index. This index indicates how many masters held a seat on the board, taking into account the number of seats

7I. Before 1540 and during the Calvinist republic the tailors' guild had 7 jurors, the brewers' guild 6 , the mercers' guild 5, the cheesemongers' and grocers' guilds 4 each, and the stocking makers' guild 3. The number of board members was determined by the number of guild members and by the degree of labour intensity of the jurors' supervisory task.

72. In the mercers' guild the dean and jurors were excluded from board membership for a period of two years after a term of office of one year: Van der Hallen, "Het Gentse meerseniersambacht", p. 108. According to the regulations of 1579 a dean in the stocking makers' guild could stay on for a maximum period of two consecutive years. Furthermore, it was not possible for a father and son, or brothers, to be members of the same guild board: series 165 , no. 9 , f. $3 \mathrm{v}$. 
Table 8. Average number of mandates per master and family + participation index of the masters in the guild board, I540-I600

\begin{tabular}{lcccccc}
\hline & Brewers & Mercers & Tailors & $\begin{array}{c}\text { Stocking } \\
\text { makers }\end{array}$ & $\begin{array}{c}\text { Cheese } \\
\text { mongers }\end{array}$ & Grocers \\
\hline Number of mandates & 157 & 132 & 135 & 122 & 105 & 125 \\
Number of mandataries & 89 & 75 & 60 & 68 & 57 & 64 \\
Average no. of mandates per & 1.8 & 1.8 & 2.3 & 1.8 & 1.8 & 2.0 \\
master & 47 & 54 & 40 & 49 & 45 & 44 \\
$\begin{array}{l}\text { Number of board families } \\
\text { Average no. of mandates per }\end{array}$ & 3.3 & 2.4 & 3.4 & 2.5 & 2.3 & 2.8 \\
family & 57 & 57 & 44 & 56 & 54 & 51 \\
Participation index & & & & & & \\
\hline
\end{tabular}

Sources: See Table 5.

available. Table 7 shows that the index in the three guilds fluctuated around 50 per cent. This percentage shows that none of the three guilds aimed to have as many members on the board as possible, because, had that been the case, the index would have been much higher. But nor can we state that the guild boards were characterized by absolute monopolization, because the index would then have been much lower. Of the three guilds the mercers' guild was the most democratic.

What was the situation like after the Concessio Carolina? Between 1540 and 1600 the average number of offices per master fluctuated between 2.3 in the tailors' guild and I.8 in most other guilds (Table 8). Again these average figures are very low. The participation index fluctuated between 44 per cent and 57 per cent. This means that in the brewers' and mercers' guilds there were more masters who held a seat on the board than in the tailors' guild. When we compare the situation in the guilds before and after I540, we find that after 1540 the mercers' guild ( 6 per cent) and especially the brewers' guild (+II per cent) admitted more masters to the board than before. In the tailors' guild there were no changes. The same evolution can be seen with respect to the board families: a status quo in the tailors' guild and a definite decrease in the number of offices per family in the brewers' guild (from 5.6 to 3.3). In spite of the enlargement of the brewers' and the mercers' guild, even after 1540 the guild boards remained midway between an oligarchic and a democratic institution.

We have also studied the frequency of mandates in the guild board. Table 9 allows us to deduce that about three-quarters of all mandataries held office for only one or at most two terms during their entire career. Again these percentages confirm that there was a very high degree of mobility among the board members. There are other figures to bear out the lower percentage in the tailors' guild (66.8 per cent). The tailors' guild had the highest average number of mandates per master (2.3), the lowest participation index (43), 
Table 9. Distribution of the number of mandates (ma) across board members (bo), $1500-1600$

\begin{tabular}{|c|c|c|c|c|c|c|c|c|c|c|c|c|}
\hline \multirow{2}{*}{$\begin{array}{l}\text { No. of } \\
\text { mandates } \\
\text { per } \\
\text { master }\end{array}$} & \multicolumn{2}{|c|}{ Brewers } & \multicolumn{2}{|c|}{ Mercers } & \multicolumn{2}{|c|}{ Tailors } & \multicolumn{2}{|c|}{$\begin{array}{c}\text { Stocking } \\
\text { makers }\end{array}$} & \multicolumn{2}{|c|}{$\begin{array}{l}\text { Cheese- } \\
\text { mongers }\end{array}$} & \multicolumn{2}{|c|}{ Grocers } \\
\hline & $\begin{array}{l}\% \\
\text { bo }\end{array}$ & $\begin{array}{c}\% \\
\mathrm{ma}\end{array}$ & $\begin{array}{l}\% \\
\text { bo }\end{array}$ & $\begin{array}{c}\% \\
\mathrm{ma}\end{array}$ & $\begin{array}{l}\% \\
\text { bo }\end{array}$ & $\begin{array}{c}\% \\
\mathrm{ma}\end{array}$ & $\begin{array}{l}\% \\
\text { bo }\end{array}$ & $\begin{array}{c}\% \\
\mathrm{ma}\end{array}$ & $\begin{array}{l}\% \\
\text { bo }\end{array}$ & $\begin{array}{c}\% \\
\mathrm{ma}\end{array}$ & $\begin{array}{l}\% \\
\text { bo }\end{array}$ & $\begin{array}{c}\% \\
\mathrm{ma}\end{array}$ \\
\hline 1 & 41.0 & 18.9 & 56.2 & 29.3 & 46.5 & 20.3 & 58.8 & 32.8 & 56.1 & 30.5 & 45.3 & 23.2 \\
\hline 2 & 33.6 & 31.0 & 18.6 & 19.3 & 20.3 & 17.7 & 20.6 & 23.0 & 22.8 & 24.7 & 32.8 & 33.6 \\
\hline 3 & 9.7 & 13.5 & 13.4 & 21.0 & 13.9 & 18.1 & 11.7 & 19.7 & 12.2 & 20.0 & 12.5 & 19.2 \\
\hline 4 & 7.8 & 14.4 & 6.7 & 14.0 & 9.4 & 16.4 & 4.4 & 9.8 & 3.5 & 7.6 & 4.6 & 9.6 \\
\hline 5 & 3.9 & 9.0 & 2.1 & 5.4 & 4.9 & 10.8 & 1.5 & 4.1 & 1.8 & 4.8 & 1.6 & 4.0 \\
\hline 6 & 1.5 & 4.0 & 1.5 & 4.8 & 3.0 & 7.7 & 1.5 & 4.9 & 1.8 & 5.7 & 1.6 & 4.8 \\
\hline 7 & 1.0 & 3.1 & 1.0 & 3.8 & 0.0 & 0.0 & 1.5 & 5.7 & 1.8 & 6.7 & 1.6 & 5.6 \\
\hline 8 & 0.5 & 1.8 & 0.0 & 0.0 & 0.0 & 0.0 & 0.0 & 0.0 & 0.0 & 0.0 & 0.0 & 0.0 \\
\hline 9 & 0.5 & 2.0 & 0.5 & 2.4 & 0.5 & 1.9 & 0.0 & 0.0 & 0.0 & 0.0 & 0.0 & 0.0 \\
\hline 10 & 0.5 & 2.3 & 0.0 & 0.0 & 0.5 & 2.1 & 0.0 & 0.0 & 0.0 & 0.0 & 0.0 & 0.0 \\
\hline 11 & 0.0 & 0.0 & 0.0 & 0.0 & 0.5 & 2.4 & 0.0 & 0.0 & 0.0 & 0.0 & 0.0 & 0.0 \\
\hline \multirow[t]{2}{*}{12} & 0.0 & 0.0 & 0.0 & 0.0 & 0.5 & 2.6 & 0.0 & 0.0 & 0.0 & 0.0 & 0.0 & 0.0 \\
\hline & 100.0 & 100.0 & 100.0 & 100.0 & 100.0 & 100.0 & 100.0 & 100.0 & 100.0 & 100.0 & 100.0 & 100.0 \\
\hline Number & 205 & 445 & 194 & 372 & 202 & 464 & 68 & 122 & 57 & 105 & 64 & 125 \\
\hline
\end{tabular}

Sources: See Table I.

Note: The figures for the brewers, mercers and tailors cover the period I500-1600, those for the stocking makers, cheesemongers and grocers cover the periods I543-I600, I540-I600 and I54II600 respectively.

the highest number of offices per master and the highest number of board members holding more than five mandates in the sixteenth century. ${ }^{73}$ From the fact that 9.9 per cent of the board members in the tailors' guild, 7.9 per cent of the board members in the brewers' guild, 5.4 per cent of the board members in the cheesemongers' guild, 5.I per cent of the board members in the mercers' guild, 4.8 per cent of the board members in the grocers' guild and only 4.5 per cent of the board members in the stocking makers' guild held more than five offices, we conclude that there were striking differences between the various guilds with regard to the degree of polarization. The highest degree of polarization was found in the tailors' guild and the lowest degree in the stocking makers' guild. To gain a clearer insight into the division of power within the guild board we also must take into account the number of board members and the number of mandates they exercised. A limited elite of about 25 per cent of the mandataries claimed half of all offices in the various guilds. ${ }^{74}$ The other half were divided across the remain-

73. The maximum number of mandates that a master held amounted to 7 in the stocking makers', cheesemongers' and grocers' guilds, 9 in the mercers' guild, Io in the brewers' guild (Jan Van den Hane) and 12 in the tailors' guild (Lieven De Durpere).

74. In the tailors' guild 24.3 per cent, in the mercers' guild 24.7 per cent, in the brewers' guild 25.4 per cent, in the cheesemongers' guild 26.3 per cent, in the stocking makers' guild 26.5 per 
ing 75 per cent of board members. These percentages show that in spite of a high degree of mobility among the board members there was always a certain group of masters with much longer terms of office, who could therefore exercise much more influence than mandataries who had to resign after one or two terms of office. ${ }^{75}$

When we focus on the families too, a certain concentration and polarization of power can be seen. In all guilds there was a significant majority of families holding only five offices (see Table Io). On the other hand, in the brewers' and tailors' guilds there were families holding more than 20 offices. The monopolization of positions on the board was most apparent in the brewers' guild. Five families held 32 per cent of all mandates. ${ }^{76}$ By way of comparison, the five principal families amongst tailors and mercers had to content themselves with I8 per cent and I9 per cent of all offices respectively. ${ }^{77}$ The concentration of board mandates within the brewers' guild does not surprise us because, as we have seen, prior to 1540 the brewers' guild had far fewer families than the other guilds. Table II shows that the concentration of power within the guild board was more pronounced before the Concessio Carolina than after. By limiting the number of jurors to two, it became far more difficult after 1540 for the masters to hold on to their seats on the board for a long time. Moreover, after 1540 it became less interesting to hold an office on the guild board since a board mandate was no longer a springboard to a political career.

The proportion of hereditary masters to non-hereditary masters in the guild board changed drastically during the course of the sixteenth century. In this regard the percentages shown in Table I2 are self-evident. Between $\mathrm{I} 500$ and 1540 the hereditary masters had a predominance in all guilds. This does not imply, however, that non-hereditary masters were excluded from

cent and in the grocers' guild 28.I per cent. Marc Boone came to similar results for late medieval Ghent: about 20 per cent of the mandataries held about half of all functions: M. Boone, "Les métiers dans les villes flamandes au bas moyen âge (XIVe-XVIe siècles): images normatives, réalités socio-politiques et économiques", in P. Lambrechts and J.-P., Sosson (eds), Les métiers au moyen âge. Aspects économiques et sociaux (Louvain-la-Neuve, I994), p. II. See also M. Boone, Gent en de Bourgondische hertogen, pp. 83-92. The same author also found that among the guilds that were permanently represented on the city council, e.g. the brewers' guild, the concentration of positions on the board was less pronounced than in other guilds. Our research, however, clearly shows that this was not the case for the brewers' guild in the sixteenth century.

75. Sosson and Mertens came to similar conclusions: J.-P. Sosson, "La structure sociale", p. 474, and J. Mertens, "De Brugse ambachtsbesturen (1363-1374, n.s.): een oligarchie?", in Recht en instellingen in de oude Nederlanden tijdens de middeleeuwen en de nieuwe tijd. Liber amicorum Jan Buntinx (Louvain, 198I), pp. I9I-192.

76. The brewers' family Van Hulse held 22 mandates in total, the families Goethals and Van den Hane 23, the Van der Beke family 34 and the Van Hoorebeke family 40 mandates.

77. The tailors' families Christiaens and Hiele held I4 mandates, the De Brune family I5, the Heyndricx family I6 and the De Waele family bore the palm with 24 mandates. In the mercers' guild the Van der Piet family filled 9 mandates, the De Gheendt family II, the families De Backers and Van Deynse Is and the Van Overwaele family 20 mandates. 
Table IO. Distribution of the number of mandates across the families, I500I600

\begin{tabular}{|c|c|c|c|c|c|c|c|c|c|c|c|c|}
\hline \multirow{3}{*}{$\begin{array}{l}\text { No. of } \\
\text { mandates } \\
\text { per } \\
\text { family }\end{array}$} & \multicolumn{2}{|c|}{ Brewers } & \multicolumn{2}{|c|}{ Mercers } & \multicolumn{2}{|c|}{ Tailors } & \multicolumn{2}{|c|}{$\begin{array}{c}\text { Stocking } \\
\text { makers }\end{array}$} & \multicolumn{2}{|c|}{$\begin{array}{l}\text { Cheese- } \\
\text { mongers }\end{array}$} & \multicolumn{2}{|c|}{ Grocers } \\
\hline & $\%$ & $\%$ & $\%$ & $\%$ & $\%$ & $\%$ & $\%$ & $\%$ & $\%$ & $\%$ & $\%$ & $\%$ \\
\hline & $\mathrm{fa}$ & $\mathrm{ma}$ & $\mathrm{fa}$ & $\mathrm{ma}$ & $\mathrm{fa}$ & $\mathrm{ma}$ & $\mathrm{fa}$ & $\mathrm{ma}$ & $\mathrm{fa}$ & $\mathrm{ma}$ & $\mathrm{fa}$ & $\mathrm{ma}$ \\
\hline $1-5$ & 64.9 & 24.5 & 88.9 & 63.3 & 79.4 & 44.8 & 93.9 & 77.0 & 91.1 & 62.9 & 91.0 & 68.8 \\
\hline $6-10$ & 20.3 & 24.9 & 7.9 & 20.2 & 12.4 & 23.9 & 4.1 & 12.3 & 6.7 & 21.9 & 4.5 & 11.2 \\
\hline $11-20$ & 8.1 & 18.7 & 3.2 & 16.5 & 7.4 & 26.1 & 2.0 & 10.7 & 2.2 & 15.2 & 4.5 & 20.0 \\
\hline \multirow[t]{2}{*}{$21-40$} & 6.7 & 31.9 & 0.0 & 0.0 & 0.8 & 5.2 & 0.0 & 0.0 & 0.0 & 0.0 & 0.0 & 0.0 \\
\hline & 100.0 & 100.0 & 100.0 & 100.0 & 100.0 & 100.0 & 100.0 & 100.0 & 100.0 & 100.0 & 100.0 & 100.0 \\
\hline Number & 74 & 445 & 126 & 371 & 121 & 460 & 49 & 122 & 45 & 105 & 44 & 125 \\
\hline
\end{tabular}

Sources: See Table I.

Note: The figures for the brewers, mercers and tailors cover the period I500-1600, those for the stocking makers, cheesemongers and grocers cover the periods I543-I600, I540-I600 and I54II600 respectively.

Table II. Number of masters with five or more mandates, I500-I600

\begin{tabular}{lrrrrrr}
\hline Mandate period & \multicolumn{2}{c}{ Brewers } & \multicolumn{2}{c}{ Mercers } & \multicolumn{2}{c}{ Tailors } \\
& no. & \multicolumn{1}{c}{$\%$} & no. & \multicolumn{1}{c}{$\%$} & no. & $\%$ \\
\hline Before 1540 & 9 & 56 & 8 & 80 & 13 & 65 \\
Before and after 1540 & 3 & 19 & 1 & 10 & 3 & 15 \\
After 1540 & 4 & 25 & 1 & 10 & 4 & 20 \\
Total & 16 & 100 & 10 & 100 & 20 & 100 \\
\hline
\end{tabular}

Sources: City Archives of Ghent, series I60, no. 6; series 178, no. I; series I9I, nos I and 2.

Table I2. Percentage of deans and jurors who were non-hereditary masters, I500-I600 (\%)

\begin{tabular}{lcccccc}
\hline Period & Brewers & Mercers & Tailors & $\begin{array}{c}\text { Stocking } \\
\text { makers }\end{array}$ & $\begin{array}{c}\text { Cheese } \\
\text { mongers }\end{array}$ & Grocers \\
\hline $1500-1540$ & 1.5 & 22.8 & 24.5 & - & - & - \\
$1540-1577$ & 2.3 & 12.2 & 32.3 & 21.1 & 25.0 & 28.2 \\
$1578-1584$ & 25.0 & 23.8 & 22.7 & 40.0 & - & 46.7 \\
$1585-1600$ & 50.0 & 50.0 & 41.2 & 71.4 & 59.1 & 58.8 \\
\hline
\end{tabular}

Sources: See Table I.

the board: in the tailors' and mercers' guilds they held about a quarter of the seats. This table also shows that the significant increase in the number of outsiders after 1540 did not immediately result in a proportional increase in non-hereditary masters on the board. During the Calvinist period this situation began to change, but the real breakthrough came after the reconciliation. From then on the boards had as many (brewers, mercers) non- 
Table i3. Number of years between the purchase of the master's title and a first mandate, $1500-1600$

\begin{tabular}{|c|c|c|c|c|c|c|c|c|c|c|c|c|}
\hline \multirow{2}{*}{$\begin{array}{l}\text { No. } \\
\text { of } \\
\text { years }\end{array}$} & \multicolumn{2}{|c|}{ Brewers } & \multicolumn{2}{|c|}{ Mercers } & \multicolumn{2}{|c|}{ Tailors } & \multicolumn{2}{|c|}{$\begin{array}{c}\text { Stocking } \\
\text { makers }\end{array}$} & \multicolumn{2}{|c|}{$\begin{array}{l}\text { Cheese- } \\
\text { mongers }\end{array}$} & \multicolumn{2}{|c|}{ Grocers } \\
\hline & no. & $\%$ & no. & $\%$ & no. & $\%$ & no. & $\%$ & no. & $\%$ & no. & $\%$ \\
\hline $1-5$ & 2 & 12.5 & 17 & 33.3 & 14 & 25.9 & 7 & 28.0 & 6 & 27.3 & 7 & 29.2 \\
\hline $6-10$ & 5 & 31.3 & 10 & 19.6 & 11 & 20.4 & 6 & 24.0 & 8 & 36.4 & 5 & 20.8 \\
\hline $11-20$ & 6 & 37.5 & 19 & 37.3 & 17 & 31.5 & 9 & 36.0 & 8 & 36.4 & 9 & 37.5 \\
\hline $21-42$ & 3 & 18.8 & 5 & 9.8 & 12 & 22.2 & 3 & 12.0 & 0 & 0.0 & 3 & 12.5 \\
\hline Total & 16 & 100.0 & 51 & 100.0 & 54 & 100.0 & 25 & 100.0 & 22 & 100.0 & 24 & 100.0 \\
\hline Median & \multicolumn{2}{|c|}{11 years } & \multicolumn{2}{|c|}{9 years } & \multicolumn{2}{|c|}{12 years } & \multicolumn{2}{|c|}{8 years } & \multicolumn{2}{|c|}{9 years } & \multicolumn{2}{|c|}{10.5 years } \\
\hline
\end{tabular}

Sources: See Table I.

Note: The figures for the brewers, mercers and tailors cover the period 1500-1600, those for the stocking makers, cheesemongers and grocers covers the periods I543-I600, I540-I600 and I54II600 respectively.

hereditary masters as hereditary masters, or even more (stocking makers, cheesemongers, grocers) non-hereditary masters. The biggest contrast is seen in two guilds in the clothing trade: stocking makers (7I.4 per cent) and tailors (4I.2 per cent). The composition of the guild boards at the end of the sixteenth century was completely different from the composition of those boards at the beginning of the century. The reason why the number of non-hereditary masters increased significantly after 1540 lies in the fact that it was the city council which decided who was to be admitted to the guild board.

How long did it take a master to become a member of the guild board? The time span between buying the title of master and holding an office could be widely differing in all guilds (Table $\mathrm{I}_{3}$ ). Some masters only needed one or two years to become a member of the board, others needed twenty to thirty years or even more. On average the stocking makers (8 years) were the quickest to become members of the board. The average waiting period was longest in the tailors' guild (I2 years). Table I4 clearly shows that the average waiting period for masters' children was considerably longer than for non-masters' children. This is completely normal because masters' children were entered in the membership records at an early age.

What can we conclude from our inquiry into mobility within the guild system? The examinations carried out with regard to the ease of access to mastership and to the guild boards indicate the following. First, the opportunities for social promotion within the guild system were, to a large extent, determined by the successive political regimes. This implies that there was no rectilinear and one-way evolution and that the guilds were strongly influenced by and subject to changes in municipal society. Second, although in other cities in the southern Netherlands the conditions of 
Table I4. Number of years between the registration of masters' children and their first mandate, I500-I600

\begin{tabular}{lrrrrrr}
\hline No. of years & \multicolumn{2}{c}{ Brewers } & \multicolumn{2}{c}{ Mercers } & \multicolumn{2}{c}{ Tailors } \\
& no. & $\%$ & no. & $\%$ & no. & $\%$ \\
\hline $1-5$ & 9 & 14.3 & 0 & 0.0 & 2 & 6.1 \\
$6-10$ & 10 & 15.9 & 2 & 6.9 & 3 & 9.1 \\
$11-20$ & 19 & 30.2 & 7 & 24.1 & 8 & 24.2 \\
$21-40$ & 22 & 34.9 & 14 & 48.3 & 14 & 42.4 \\
$>40$ & 3 & 4.8 & 6 & 20.7 & 6 & 18.2 \\
Total & 63 & 100.0 & 29 & 100.0 & 33 & 100.0 \\
Median & \multicolumn{2}{c}{17 years } & \multicolumn{2}{c}{27 years } & 22 years \\
\hline
\end{tabular}

Sources: City Archives of Ghent, series I60, no. 6; series 178, no. I; series 191, nos I and 2.

admission to mastership were systematically made more difficult, the situation in Ghent was clearly different. Third, before 1540 most guilds were less closed than has generally been assumed up to now. Fourth, the Concessio Carolina created real opportunities for upward mobility. Fifth, the frequent occurrence of double membership proves that the professional separation between certain guilds was, in reality, far less strict than the by-laws of the guilds would imply. Sixth, only a minority of masters managed to get a position on the board. Seventh, the guild boards cannot be described as clearly democratic nor as distinctly oligarchic institutions. Finally, the proportion of masters' children to non-masters' children was significantly altered, both with regard to mastership and membership of the board, in favour of the latter group.

\section{SOCIAL STATUS OF GUILD MASTERS}

Everybody will no doubt agree that a person's social status is not determined by one element only, but rather by the combination of the various positions of this person in the various domains of social life (the social, economic, juridical, political, religious and cultural domains). In order accurately to determine someone's place in society, a number of different criteria should be used. For lack of sufficient and adequate source material this is an almost impossible task, at least as far as the early modern period and particularly the sixteenth century is concerned. Using the source material available we studied the social status of the guild masters on the basis of the houses they lived in. We may assume that practically everybody lived in a house the value of which was proportionate to the occupant's financial means. Not only the financial position of the owners or tenants played a role in their choice of houses, but also the awareness of their social status. Therefore, the quality and dimensions of the houses reflect the occupants' social position. The advantage of examining social status on the basis of the housing 


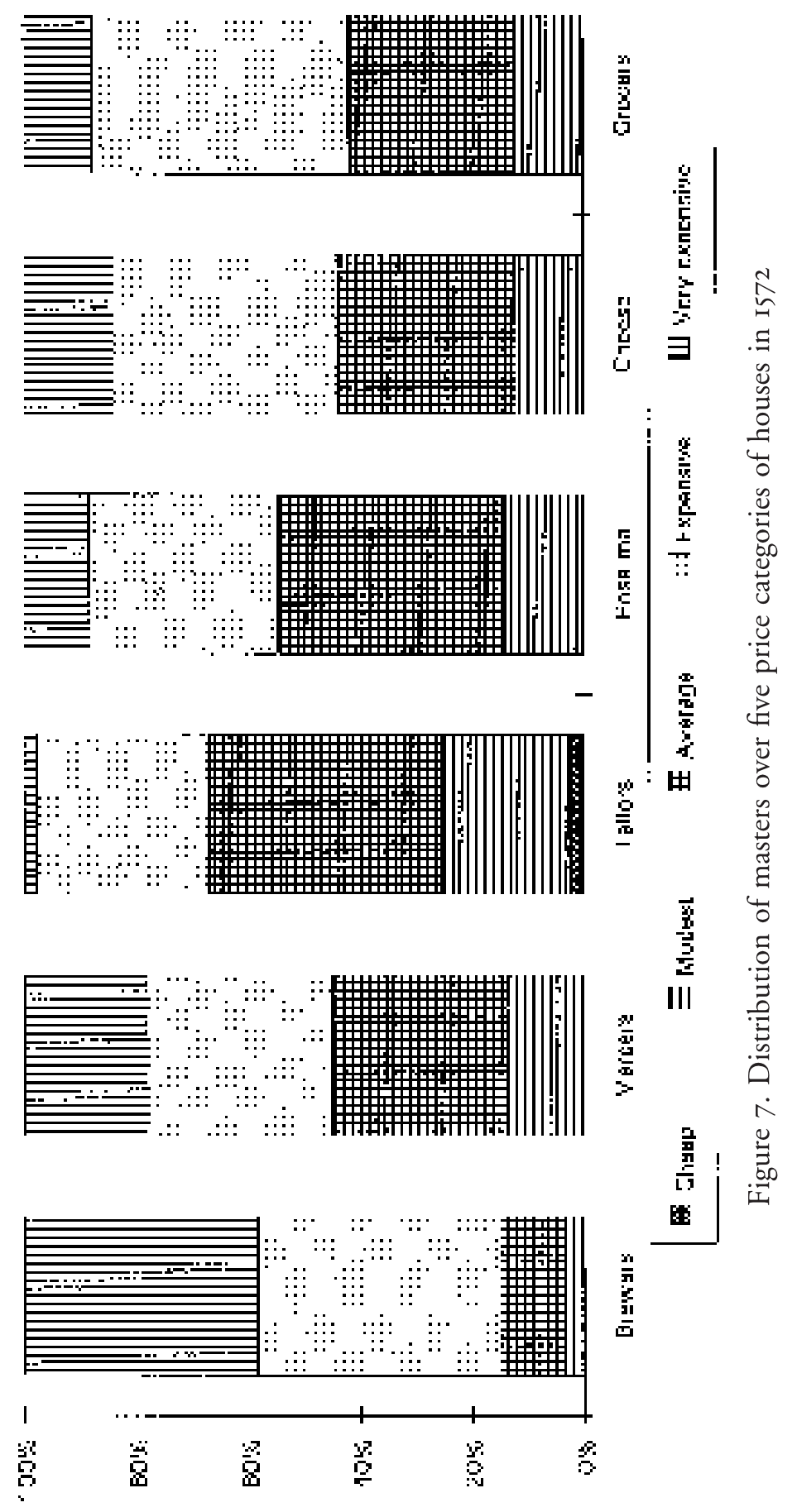


Table I5. Median, mean, minimum and maximum annual rental value of masters' houses in 1572 expressed in Flemish groats

\begin{tabular}{lrrrrrr}
\hline & Brewers & Mercers & Tailors & $\begin{array}{c}\text { Stocking } \\
\text { makers }\end{array}$ & $\begin{array}{c}\text { Cheese } \\
\text { mongers }\end{array}$ & Grocers \\
\hline Median & 1,680 & 1,020 & 600 & 840 & 984 & 960 \\
Mean & 1,660 & 1,216 & 763 & 972 & 1,148 & 1,091 \\
Minimum & 240 & 240 & 120 & 240 & 240 & 240 \\
Maximum & 4,080 & 3,720 & 3,360 & 2,880 & 2,880 & 2,880 \\
No. of houses & 87 & 129 & 91 & 86 & 50 & 74 \\
\hline
\end{tabular}

Sources: City Archives of Ghent, series 153/2, nos 2-39; series I60, no. 6; series I78, no. I; series I9I, nos I and 2; series 165 , no. 2; series I7I/I, no. I; series 172 , nos 3 and 4.2 .

culture is that, on the one hand, a much larger part of the population can be classified according to the same uniform criterion than would be possible if we used income or property taxes, and, on the other hand, the dwelling covers all other elements which determine an individual's social rank or status (profession, income, property, taxes paid, etc.). ${ }^{78}$

Thanks to the 2oth penny tax registers of $157 \mathrm{I}-1572$, which have, for the greater part, been preserved, it was possible to retrieve data on the annual rental value of most houses in Ghent. ${ }^{79}$ The main disadvantage of these penny tax rolls is that they hardly ever mention professions and consequently they proved to be impractical for determining the social position of master craftsmen. We filled this void by linking the records of membership of the six guilds to the Ghent records of owners and tenants. This was a very labour-intensive job, because all the first names and surnames had to be made uniform in both files before the computer could link the data and we could not retrace every master in the land register. There are various reasons for this. Masters who had emigrated or died or who lived with another person or rented a house from a sublessor were not recorded in the penny registers. Furthermore, there was the problem of the many homonyms. For our prosopographic research we used the information available only if we were certain that the master's name to which both sources referred actually related to one and the same person.

The first conclusion we can draw is that the average value of a master's house could vary tremendously according to the master's guild affiliation (Table I5). The brewers were undoubtedly the most prosperous group. The

78. See J. Hannes, "L'habitation, phénomène économique et social”, Belgisch Tijdschrift voor Nieuwste Geschiedenis, 2 (1970), pp. I23-I44.

79. The I57I-I572 tax registers of I2.5 out of the total of I5 quarters of the city of Ghent have been preserved. For the remaining 2.5 quarters we consulted two Iooth penny tax registers of 1569 and one 5th penny tax register of 1577 . That way it was possible to reconstruct the complete land register of the city of Ghent: series $153 / 2$, nos 2-39. The 20 th, Iooth and 5 th penny were levies of respectively 5, I and 20 per cent on the rateable value (the real and fictitious annual rental value) of real property in the county of Flanders. 
Table i6. Number of board members and ordinary masters who had to contribute to the mandatory loan of 1578

\begin{tabular}{|c|c|c|c|c|c|c|c|c|c|c|c|c|}
\hline \multirow{2}{*}{$\begin{array}{l}\text { Amount } \\
\text { in } \\
\text { gr. }\end{array}$} & \multicolumn{2}{|c|}{ Brewers } & \multicolumn{2}{|c|}{ Mercers } & \multicolumn{2}{|c|}{ Tailors } & \multicolumn{2}{|c|}{$\begin{array}{c}\text { Stocking } \\
\text { makers }\end{array}$} & \multicolumn{2}{|c|}{$\begin{array}{l}\text { Cheese- } \\
\text { mongers }\end{array}$} & \multicolumn{2}{|c|}{ Grocers } \\
\hline & board & ord & board & ord & board & ord & board & ord & board & ord & board & ord \\
\hline 16,000 & 0 & 0 & 0 & 0 & 0 & 0 & 0 & 0 & 0 & 0 & 1 & 0 \\
\hline 12,000 & 0 & 0 & 1 & 0 & 0 & 0 & 0 & 0 & 0 & 0 & 0 & 0 \\
\hline 6,000 & 0 & 0 & 1 & 0 & 0 & 1 & 0 & 0 & 2 & 0 & 0 & 0 \\
\hline 4,000 & 3 & 1 & 11 & 0 & 1 & 0 & 0 & 0 & 3 & 2 & 4 & 1 \\
\hline 2,000 & 9 & 1 & 7 & 10 & 3 & 0 & 2 & 3 & 4 & 0 & 4 & 1 \\
\hline Total & 12 & 2 & 20 & 10 & 4 & 1 & 2 & 3 & 9 & 2 & 9 & 2 \\
\hline
\end{tabular}

Sources: See Table I. Despretz, "De instauratie", pp. II9-229.

purchase price of a brewery was considerably higher than that of an average dwelling. ${ }^{80}$ The mercers ranked second, followed by the other two trade guilds. ${ }^{81}$ The masters belonging to the clothes trade lived in the least expensive houses. The fact that there was only a small difference between the average value of houses of cheesemongers and houses of grocers confirms that both guilds were interwoven through double membership. The same goes for tailors and stocking makers. It is interesting to test our results by linking them to a fiscal list that has been preserved in which the 497 wealthiest citizens - about 5 per cent of the total population of Ghent - are listed. In March 1578 these citizens had to grant a mandatory loan in favour of the States General. ${ }^{82}$ The six guilds together accounted for a total of 76 taxed citizens, which is 15.3 per cent of the total number of taxed townspeople. ${ }^{83}$ Ninety-two per cent of the taxed masters paid 2,000 or 4,000 gr., respectively 83 and 166 summer day wages of a journeyman bricklayer. Table I6 bears out the prosperity ratio between the guilds as already established on the basis of the rental value of the houses. Taking into account the total number of guild members, the brewers, followed by the three trade guilds,

80. See J. Dambruyne, "Conjunctuur, stratificatie en koopkracht te Gent tijdens de eerste helft van de I7de eeuw. De economische en sociale betekenis van de rente- en woningmarkt", Handelingen der Maatschappij voor Geschiedenis en Oudheidkunde te Gent, 43 (1989), p. 156; Soly, "De economische betekenis", p. IIo.

8I. Numerous mercers lived in the Langemunt, one of the most important and expensive shopping streets of sixteenth-century Ghent.

82. For the list of names of the lenders see A. Despretz, "De instauratie der Calvinistische republiek (1577-1579)", Handelingen der Maatschappij voor Geschiedenis en Oudheidkunde te Gent, I7 (1963), pp. II9-229. The loans fluctuated between 2,000 and I60,000 gr. We may assume that the lenders' share in the obligatory loan was proportional to their wealth and property.

83. In Nördlingen too a fair number of masters formed part of the city's fiscal elite in 1579: Friedrichs, Urban Society, p. I09. The most highly taxed master in Ghent in 1578 was Jan Bollaert, a grocer. Bollaert, who was juror in 1566 and I57I and dean of the grocers' guild as well as overdean of the small guilds in $1583-1584$, lent 16,000 gr., the equivalent of 667 summer days wages of a journeyman bricklayer. 
contributed most to the compulsory loan. Tailors and stocking makers, however, were not well represented among the lenders. ${ }^{84}$ This order of ranking fits in very well with the social status of the various guilds. As a rule the trade guilds enjoyed more prestige than the manufacturing guilds. All over Europe mercers took pride in the fact that they did not do manual labour. ${ }^{85}$ But among the manufacturing guilds too there was a hierarchical structure; guilds producing delicate and high quality custom-made goods enjoyed higher status than guilds producing bulk goods ${ }^{86}$ It is obvious that the guild to which a master belonged determined to a large extent his social status and wealth.

To gain a better insight into the division of wealth between and within the guilds, we categorized the masters into five groups depending on the value of the houses they lived in. The sharp contrast between the richest and the poorest guilds is clearly shown in Table 17: only 3.4 per cent of the brewers lived in a cheap or modest house, whereas this was the case for 25.3 per cent of the tailors; 85.I per cent of the brewers lived in expensive or very expensive premises, whereas the same was true of only 33 per cent of the tailors. Although all guilds are represented in nearly all five categories, there are certain concentrations. From the fact that mercers, grocers, cheesemongers, stocking makers and tailors had a numerical preponderance in the third and fourth categories, we can conclude that the majority of masters belonged to the middling groups. It also appears that far more grocers, cheesemongers and mercers than tailors can be rated among the upper middle class. The overwhelming predominance of brewers in the two highest price categories (85.I per cent) proves that the majority of brewers belonged to the upper middle class. ${ }^{87}$ That is why the brewers' guild is,

84. In the fiscal registers of Antwerp for the year $1584-1585$ the two highest fiscal groups also consisted of several brewers, grocers and mercers. Tailors or stocking makers were not represented in these groups: J. Van Roey, "De correlatie tussen het sociale-beroepsmilieu en de godsdienstkeuze te Antwerpen op het einde der XVIe eeuw”, in Bronnen voor de religieuze geschiedenis van België, Middeleeuwen en Moderne Tijden. Verslag Colloquium over Religieuze Geschiedenis, Brussel, I967 (Louvain, 1968), p. 248. See also Friedrichs, The Early Modern City, p. I5I; R. Van Uytven, "Bronnen en methoden voor de studie van de vermogensgroepen in de steden (I4e-I6e eeuw)", in Handelingen van het XXVIe Vlaams filologencongres (Ghent, I967), pp. 389-39I.

85. R. Mackenney, Tradesmen and Traders. The World of the Guilds in Venice and Europe, c.I250c.1650 (London and Sydney, 1987), p. 90; S.L. Kaplan, "The Luxury Guilds in Paris in the Eighteenth Century", Francia, 9 (I98I), pp. 272-273; Coornaert, Les corporations, p. 282.

86. R. Van Uytven, "Vers un autre colloque: hiérarchies sociales et prestige au Moyen Age et aux Temps Modernes", in W. Prevenier, R. Van Uytven and E. Van Cauwenberghe (eds), Structures sociales et topographie de la pauvreté et de la richesse aux I4e et Ise siècles. Aspects méthodologiques et résultats de recherches récentes. Actes du colloque tenu à Gand le 24 mai 1985 (Ghent, I986), pp. I62I63. See also W.C. Ultee, "Het aanzien van beroepen, op andere plaatsen en vooral in andere tijden. Een analyse van een aantal recente historische studies", Tijdschrift voor Sociale Geschiedenis, 9 (I983), pp. $28-48$.

87. Our results largely confirm the findings of an inquiry into the socio-professional groups that were active in the Ghent rental and real-estate market at the end of the fifteenth and at the beginning of the sixteenth centuries. It appears that master craftsmen from the victualling sector (e.g. the brewers) were much more involved in rent and real-estate transactions than master 
Table 17. Distribution of masters over five price categories of houses in 1572

\begin{tabular}{|c|c|c|c|c|c|c|c|c|c|c|c|c|}
\hline \multirow[t]{2}{*}{ Category } & \multicolumn{2}{|c|}{ Brewers } & \multicolumn{2}{|c|}{ Mercers } & \multicolumn{2}{|c|}{ Tailors } & \multicolumn{2}{|c|}{$\begin{array}{c}\text { Stocking } \\
\text { makers }\end{array}$} & \multicolumn{2}{|c|}{$\begin{array}{l}\text { Cheese- } \\
\text { mongers }\end{array}$} & \multicolumn{2}{|c|}{ Grocers } \\
\hline & no. & $\%$ & no. & $\%$ & no. & $\%$ & no. & $\%$ & no. & $\%$ & no. & $\%$ \\
\hline Cheap 5-239 & 0 & 0.0 & 0 & 0.0 & 2 & 2.2 & 0 & 0.0 & 0 & 0.0 & 0 & 0.0 \\
\hline $\begin{array}{l}\text { gr. } \\
\text { Modest } 240- \\
479 \text { gr. }\end{array}$ & 3 & 3.4 & 18 & 14.0 & 21 & 23.1 & 12 & 14.0 & 6 & 12.0 & 9 & 12.2 \\
\hline $\begin{array}{l}\text { Average } 480- \\
959 \text { gr. }\end{array}$ & 10 & 11.5 & 40 & 31.0 & 38 & 41.7 & 35 & 40.7 & 16 & 32.0 & 22 & 29.7 \\
\hline $\begin{array}{l}\text { Expensive } 960- \\
1,919 \text { gr. }\end{array}$ & 38 & 43.7 & 43 & 33.3 & 28 & 30.8 & 29 & 33.7 & 20 & 40.0 & 34 & 45.9 \\
\hline $\begin{array}{l}\text { Very expensive } \\
1,920-14,400 \\
\text { gr. }\end{array}$ & 36 & 41.4 & 28 & 21.7 & 2 & 2.2 & 10 & 11.6 & 8 & 16.0 & 9 & 12.2 \\
\hline Total & 87 & 100.0 & 129 & 100.0 & 91 & 100.0 & 86 & 100.0 & 50 & 100.0 & 74 & 100.0 \\
\hline
\end{tabular}

Sources: City Archives of Ghent, series I53/2, nos 2-39; series I60, no. 6; series I78, no. I; series I9I, nos I and 2; series I65, no. 2; series I7I/I, no. I; series I72, nos 3 and 4 .

Note: The distribution of the masters' houses over five price categories is based on the median of all rental values of Ghent dwellings (more than 8,000) in I57I-I572. The median value was $480 \mathrm{gr}$.

from a social point of view, the most homogeneous group of all the guilds that were examined. The frequent disputes between brewers of the cheaper and the more expensive types of ale and the price differences between the breweries - some breweries were three times more expensive than others indicate, however, that the brewers' guild cannot be depicted as a monolithic social bloc. ${ }^{88}$

Thus far we have made no distinction between hereditary masters and non-hereditary masters. The question arises whether this juridical distinction was reflected in the houses masters lived in. Table I8 shows that, as a rule, hereditary masters lived in more expensive houses than their colleagues. Especially with the mercers the price difference was striking: the mercantile houses of masters' children were twice as expensive as those of non-masters' children, which indicates that there was a considerable social gap between the hereditary and the non-hereditary masters of the guild. In this context it is also interesting to study the proportion of owners to tenants (Table 19). Although the owners had a numerical preponderance in all guilds, ${ }^{89}$ there was again a remarkable difference between hereditary and non-

craftsmen from the clothing sector. See M. Boone, M. Dumon and B. Reusens, Immobiliënmarkt, fiscaliteit en sociale ongelijkheid te Gent, I483-I503 (Courtrai and Heule, I98I), pp. 208-2II.

88. Concerning the differences, see series I60, no. 6, f. I07r. Concerning the social heterogeneity of the guilds, see Friedrichs, "Capitalism", pp. 29, 39; Cerutti, "Group strategies", p. I03.

89. The brewers had the largest number of owners ( 78.2 per cent), followed by the cheesemongers ( 72 per cent), grocers $(63.5$ per cent), tailors (61.5 per cent), mercers ( 58.9 per cent) and stocking makers ( 57 per cent). 
Table I8. Median and average annual rental value of the houses of hereditary and non-hereditary masters in 1572 expressed in Flemish groats

\begin{tabular}{lcccccc}
\hline & \multicolumn{2}{c}{ Brewers } & \multicolumn{2}{c}{ Mercers } & \multicolumn{2}{c}{ Tailors } \\
hereditary & $\begin{array}{c}\text { non- } \\
\text { hereditary }\end{array}$ & hereditary & $\begin{array}{c}\text { non- } \\
\text { hereditary }\end{array}$ & hereditary & $\begin{array}{c}\text { non- } \\
\text { hereditary }\end{array}$ \\
\hline Median & 1,680 & 1,440 & 1,920 & 840 & 720 & 600 \\
Average & 1,671 & 1,525 & 2,093 & 1,079 & 786 & 749 \\
\hline
\end{tabular}

Sources: City Archives of Ghent, series 153/2, nos 2-39; series 160, no. 6; series 178, no. I; series I9I, nos I and 2.

Table 19. Proportion of owners to tenants among hereditary and non-hereditary masters in 1572

\begin{tabular}{lcccccc}
\hline Category & \multicolumn{2}{c}{ Brewers } & \multicolumn{2}{c}{ Mercers } & \multicolumn{2}{c}{ Tailors } \\
& $\%$ & $\%$ non- & $\%$ & $\%$ non- & $\%$ & $\%$ non- \\
& hereditary & hereditary & hereditary & hereditary & hereditary & hereditary \\
\hline Owners & 88.2 & 69.8 & 70.8 & 57.0 & 87.5 & 53.4 \\
Tenants & 11.8 & 30.2 & 29.2 & 43.0 & 12.5 & 46.6 \\
Total & 100.0 & 100.0 & 100.0 & 100.0 & 100.0 & 100.0 \\
\hline
\end{tabular}

Sources: See Table I8.

hereditary masters. In the brewers' guild there were 18.4 per cent more owners among the hereditary masters than among the non-hereditary masters. In the mercers' guild the corresponding figure was 13.8 per cent and in the tailors' guild it was high as 34.I per cent.

The study of houses provides us with an answer to the question of whether there was a correlation between the administrative and the financial-economic elite of the guilds. Table 20 shows that in all guilds the deans and jurors lived in more expensive houses than the ordinary masters. The difference in wealth was particularly large in the mercers' and grocers' guild (at least 30 per cent). The contrast was least in the brewers' guild, which again proves that, from a social point of view, this guild had a more homogeneous character than the others. The connection between wealth, status and holding the most influential and prestigious offices within the guilds clearly manifested itself in the mandatory loan of 1578 (see Table I6). Among the brewers 85.7 per cent of the taxed masters were members of the board, among the mercers 66.6 per cent, among the tailors 80 per cent, and among the cheesemongers and grocers $8 \mathrm{I} .8$ per cent. ${ }^{90}$

90. A fine example of the strong bonds that existed between the administrative and financialeconomic elite was brewer Jacob Van Hoorebeke. In 1583 this descendant of the most prominent family of brewers in Ghent not only had the largest output of beer; he also held a number of important offices within the guild: juror in 1578-1579, huismeester in 1579-1580, and last but not 
Table 20. Median and average annual rental value of the houses inhabited by sitting and former board members in 1572 expressed in Flemish groats

\begin{tabular}{lcccccccrrrrrrrr}
\hline & \multicolumn{2}{c}{ Brewers } & \multicolumn{2}{c}{ Mercers } & \multicolumn{3}{c}{ Tailors } & \multicolumn{3}{c}{ Stocking } & \multicolumn{2}{c}{ Cheese- } & \multicolumn{2}{c}{ Grocers } \\
makers & \multicolumn{2}{c}{ mongers } \\
& board & all & board & all & board & all & board & all & board & all & board & all \\
\hline Median & 1,920 & 1,680 & 1,620 & 1,020 & 780 & 600 & 960 & 840 & 1,140 & 984 & 1,320 & 960 \\
Average & 1,827 & 1,660 & 1,666 & 1,216 & 913 & 763 & 1,197 & 972 & 1,289 & 1,148 & 1,426 & 1,091 \\
\hline
\end{tabular}

Sources: City Archives of Ghent, series 153/2. nos 2-39; series I60, no. 6; series I78, no. I; series I9I, nos I and 2; series I65, no. 2; series I7I/I, no. I; series I72, nos 3 and 4 .

Note: all $=$ rental value of all houses inhabited by masters (including the board members).

So far we have presented a static picture of the social positions of master craftsmen in Ghent in 1572 . Since a municipal society is constantly evolving, this implies that the social position of the individuals within this society is subject to change. A more dynamic approach to the masters' social status is required. As yet few or no concrete inquiries have been made into the relationship between the social mobility of master craftsmen and their age. ${ }^{9 r}$ In this respect Giovanni Levi's article, which examines the connection between age, profession and property in various socio-professional groups in eighteenth-century Turin, sheds new light on this subject. ${ }^{92}$ Levi came to the surprising conclusion that occupational seniority was far less a determinant of masters' fortunes than was generally assumed up to now. We have made a similar inquiry into two successive generations of master craftsmen who bought the freedom from one of the six guilds between I543 and 1572 (Table 2I). ${ }^{93}$ We find that among brewers and mercers the younger generation (1558-I572) lived in more expensive houses than the older generation (I543-I557). In the brewers' guild the median value varied by 33 per cent and in the mercers' guild by as much as 42 per cent. In the other

least dean in $158 \mathrm{I}-1582$. Next to his brewery (with an annual rental value of I,920 gr.) he owned three houses, which he rented out for 600, 240 and 336 gr. per year respectively. In the obligatory loan of 1578 he was taxed at 2,000 gr., and in the reconciliation taxes of 1584 and 1585 he was taxed at I2,000 and 4,800 gr. respectively: series I6o, no. 6; series 94bis, no. 46; series I53/2, no. 26; Despretz, "De instauratie", p. 218; De Commer, "De brouwindustrie", 37, p. 128.

9I. Friedrichs examined wealth mobility in the city of Nördlingen for a period of nearly 150 years: see his Urban Society, pp. III-I43, 326-329.

92. G. Levi, "Carrières d'artisans et marché du travail à Turin (XVIIIe-XIXe siècles)", Annales $E S C, 45$ (1990), pp. 135I-1364.

93. It was not possible to make a similar inquiry with regard to masters' children because, on the one hand, there was not enough source material available and, on the other, we do not know when the career of masters' children started exactly. Moreover, we do not know whether the majority of them actually practised the trade. As mentioned before, we were unable to retrace a large part of the master purchasers in the penny tax registers. Originally we had intended to study three generations over ten years, but since this method did not provide us with enough masters for certain generational groups, we eventually opted for two generations over is years. We could identify $5 \mathrm{I}$ per cent of the brewers, 48 per cent of the mercers, $5 \mathrm{I}$ per cent of the cheesemongers, 47 per cent of the grocers, 45 per cent of the tailors and 44 per cent of the stocking makers. 
Table 2I. Median and average annual rental value of the houses of two generations of non-hereditary masters in 1572 expressed in Flemish groats

\begin{tabular}{|c|c|c|c|c|c|c|c|c|c|c|c|c|}
\hline \multirow[t]{2}{*}{$\begin{array}{l}\text { Gen- } \\
\text { eration }\end{array}$} & \multicolumn{2}{|c|}{ Brewers } & \multicolumn{2}{|c|}{ Mercers } & \multicolumn{2}{|c|}{ Tailors } & \multicolumn{2}{|c|}{$\begin{array}{c}\text { Stocking } \\
\text { makers }\end{array}$} & \multicolumn{2}{|c|}{$\begin{array}{l}\text { Cheese- } \\
\text { mongers }\end{array}$} & \multicolumn{2}{|c|}{ Grocers } \\
\hline & $\begin{array}{l}\text { me- } \\
\text { dian }\end{array}$ & $\begin{array}{l}\text { aver- } \\
\text { age }\end{array}$ & $\begin{array}{l}\text { me- } \\
\text { dian }\end{array}$ & $\begin{array}{l}\text { aver- } \\
\text { age }\end{array}$ & $\begin{array}{l}\text { me- } \\
\text { dian }\end{array}$ & $\begin{array}{l}\text { aver- } \\
\text { age }\end{array}$ & $\begin{array}{l}\text { me- } \\
\text { dian }\end{array}$ & $\begin{array}{l}\text { aver- } \\
\text { age }\end{array}$ & $\begin{array}{l}\text { me- } \\
\text { dian }\end{array}$ & $\begin{array}{l}\text { aver- } \\
\text { age }\end{array}$ & $\begin{array}{l}\text { me- } \\
\text { dian }\end{array}$ & $\begin{array}{l}\text { aver- } \\
\text { age }\end{array}$ \\
\hline $1543-1557$ & 1,200 & 1,197 & 720 & 875 & 600 & 767 & 780 & 830 & 1,008 & 1,076 & 960 & 973 \\
\hline $1558-1572$ & 1,590 & 1,749 & 1,020 & 1,230 & 660 & 794 & 720 & 896 & 960 & 1,188 & 900 & 1,009 \\
\hline
\end{tabular}

Sources: See Table 20.

Note: For the generation $1543-1557$ the median and the average are calculated for 20 brewers, 50 mercers, 47 tailors, 22 stocking makers, 2I cheesemongers and 25 grocers, and for the generation $1558-1572$ for 22 brewers, 47 mercers, I9 tailors, 52 stocking makers, 26 cheesemongers and 32 grocers.

guilds there was only a small difference in the rental values of the houses of both generations. The most remarkable finding is that it was not necessarily the generation that had worked longest - and would therefore be expected to have accumulated the most capital and property - that lived in the most expensive houses. That was true of all the guilds. In none of the six guilds could a positive relationship be found between the length of a career and a person's fortune. Thus our results corroborate Levi's findings.

How can one explain why the younger generation of brewers and mercers appeared to be more prosperous than their older colleagues? A possible explanation might be that the younger generation mainly consisted of tenants, whereas the older generation consisted mostly of owners. Since owners have to immobilize part of their capital, the older masters switched from a more expensive rented house to a cheaper dwelling of their own. To test whether this theory corresponds with reality we examined the proportion of owners to tenants in both generations (Table 22). This shows that in all guilds there were more owners in the older generation than in the younger one. Especially in the tailors' guild $(+40.9$ per cent), the mercers' guild ( +27 per cent) and the grocers' guild (+20.6 per cent) there was a considerable contrast. Another reason for the success of the younger generation of masters is probably to be found in the economic boom. ${ }^{94}$ The Peace of Cateau-Cambrésis (I559) marked the beginning of a new period of increasing economic activity in the Low Countries. ${ }^{95}$ The evolution of the nominal rent index in Ghent gives us an idea of the economic trend: the index increased by 12 per cent between 1543 and 1557, but between 1558 and 1572 it increased by 22 per

94. For the correlation between economic climate and mobility of wealth, see Friedrichs, "Capitalism”, p. 38 .

95. For an overview of the economic climate in the Low Countries during the period I543-1572, see H. Van der Wee, The Growth of the Antwerp Market and the European Economy (FourteenthSixteenth Centuries), II (The Hague, 1963), pp. 177-243. 
Table 22. Proportion of owners to tenants for two generations of non-hereditary masters in 1572

\begin{tabular}{|c|c|c|c|c|c|c|c|c|c|c|c|c|}
\hline \multirow[t]{2}{*}{$\begin{array}{l}\text { Gen- } \\
\text { eration }\end{array}$} & \multicolumn{2}{|c|}{ Brewers } & \multicolumn{2}{|c|}{ Mercers } & \multicolumn{2}{|c|}{ Tailors } & \multicolumn{2}{|c|}{$\begin{array}{c}\text { Stocking } \\
\text { makers }\end{array}$} & \multicolumn{2}{|c|}{$\begin{array}{l}\text { Cheese- } \\
\text { mongers }\end{array}$} & \multicolumn{2}{|c|}{ Grocers } \\
\hline & $\begin{array}{c}\% \\
\text { owner }\end{array}$ & $\begin{array}{c}\% \\
\text { tenant }\end{array}$ & $\begin{array}{c}\% \\
\text { owner }\end{array}$ & $\begin{array}{c}\% \\
\text { tenant }\end{array}$ & $\begin{array}{c}\% \\
\text { owner }\end{array}$ & $\begin{array}{c}\% \\
\text { tenant }\end{array}$ & $\begin{array}{c}\% \\
\text { owner }\end{array}$ & $\begin{array}{c}\% \\
\text { tenant }\end{array}$ & $\begin{array}{c}\% \\
\text { owner }\end{array}$ & $\begin{array}{c}\% \\
\text { tenant }\end{array}$ & $\begin{array}{c}\% \\
\text { owner }\end{array}$ & $\begin{array}{c}\% \\
\text { tenant }\end{array}$ \\
\hline $1543-1557$ & 70.0 & 30.0 & 70.2 & 29.8 & 59.1 & 40.9 & 52.0 & 48.0 & 70.6 & 29.4 & 73.9 & 26.1 \\
\hline $1558-1572$ & 68.4 & 31.6 & 43.2 & 56.8 & 18.2 & 81.8 & 50.0 & 50.0 & 66.7 & 33.3 & 53.3 & 46.7 \\
\hline
\end{tabular}

Sources: See Table 20.

Note: For the generation I543-I557 the percentages are based on 20 brewers' houses, 50 mercers' houses, 47 tailors' houses, 22 stocking makers' houses, 2 I cheesemongers' houses and 25 grocers' houses, and for the generation $1558-1572$ on 22 brewers' houses, 47 mercers' houses, 19 tailors' houses, 52 stocking makers' houses, 26 cheesemongers' houses and 32 grocers' houses.

cent. $^{96}$ It seems logical for tradesmen and craftsmen to have taken business risks (such as occupying bigger and more expensive houses) during a period of economic growth than in a period of economic recession.

\section{CONCLUSIONS}

Much research remains to be done before we can gain a clear insight into the role guilds played in upward social mobility during the early modern period. In this article we have examined only six of the more than fifty guilds existing in Ghent in the sixteenth century. We particularly focused on guilds closely related to the local market. Although this inquiry does not allow us to paint an overall picture of the Ghent guilds, it does reveal a certain number of patterns of social mobility.

On the basis of the guilds that were examined it may be concluded that the Ghent guilds in the sixteenth century did not show a static picture of social mobility. Furthermore it is clear that we are not dealing with a rectilinear and one-way evolution. There are certain marked tendencies which were closely connected with the successive political regimes in the city. The years $1500-1540$ can be regarded as a period in which opportunities for upward mobility were very restricted. The high financial conditions of admission hampered the social improvement of many craftsmen. Only prospective masters from well-to-do families who could draw upon the necessary social relations were able to obtain the title of master. But in the light of their familial background these masters are proof not of upward mobility but rather of social stagnation. Yet it would be wrong to speak of exclusivism and heredity. The fairly high number of registrations of non-masters'

96. D. Van Ryssel, De Gentse huishuren tussen I500 en I795. Bijdrage tot de kennis van de konjunktuur van de stad (Brussels, I967), pp. I02-103. 
children in the mercers' guild and in the tailors' guild proves undeniably that there were new members joining the guilds. The traditional depiction of a closed guild system must therefore be qualified. The example of the Ghent brewers has been overgeneralized.

The period after 1540 was totally different; it was a time in which municipal society was very welcoming to young and skilled craftsmen and tradesmen. Burghership was free and it was fairly easy to be admitted to mastership. The result was that the number of new masters increased spectacularly in all guilds. The increasing number of registrations and the low entry fee undeniably prove the existence of upward mobility between I540 and I577. However, during the period of the Calvinist republic, which saw the restoration of the pre-I540 political and social order, the opportunities for real social improvement were again drastically reduced. The fact that, in spite of the high admission fees, there were still a considerable number of citizens who bought the title of master, proves that these people belonged to the higher social classes. After the short Calvinist intermezzo social mobility reached its sixteenth-century peak. In comparison with the total working population, the percentage of new masters was highest in that period. It is evident that the intervention of Charles V in 1540 with regard to mastership resulted in a drastic change in the guilds. The Concessio Carolina did not only change the political and institutional structures of the city; it also brought drastic changes to social structures.

Several authors are correct in pointing out that the participation of guilds in political power reinforced the tendency in Flemish and German cities to close and monopolize the guilds, because in those circumstances being a member of a guild was not only the gateway to the labour market but also to a political career. ${ }^{97}$ We believe that this connection, which has clearly been demonstrated, also applies to sixteenth-century Ghent. It is striking that before 1540 and during Calvinist rule, when the guilds had a seat on many councils of the city, it was much more difficult for an outsider to gain access to a guild. Although the opportunities for upward social mobility within the Ghent guilds were to a high degree determined by the politicalinstitutional order, it cannot be denied that demographic and economic developments also played a role. The period between $1585-1600$ provides the best demonstration of this phenomenon. Massive emigration, which resulted in a lack of skilled craftsmen on the labour market, and the deliberate policy of the government to keep admission fees particularly low, caused the guilds to be flooded with newcomers.

At first sight there seems to be great generational continuity within the Ghent guilds. However, the membership records are misleading because only an (unknown) proportion of masters' children whose names were 
entered in the registers actually followed in their father's footsteps. However, it cannot be denied that masters' children occupied prominent positions in the Ghent guilds, especially until the end of the Calvinist republic. As a rule they were superior to non-masters' children, both in terms of power (they held seats on the guild boards) and material property (they owned more expensive houses and there were far more owners among them). Yet neither the hereditary masters nor the non-hereditary masters should be depicted as a monolithic bloc. There were substantial social differences within both juridical groups. Neither can one ignore the fact that in the long term the position of the hereditary masters was on the wane. They did not manage to consolidate their status. The growing number of outsiders and their increasing influence in the guild boards indicate a higher degree of intergenerational occupational mobility after 1540 .

Yet the opportunities for upward mobility within the guilds were limited. Only a few masters managed to join the elite, the guild board. Masters of smaller guilds were undoubtedly favoured by the fact that those guilds had far fewer members. Yet we find that even in those guilds fewer than one-fifth of masters held an office. That the guilds deliberately limited the size of the corporative elite is a result of the fact that in all guilds the number of masters who actually held a seat on the board was only half the number of masters who would, theoretically speaking, have been able to hold an office. On the other hand there was a high degree of mobility within the group of mandataries: on average, a master did not hold more than two offices. In spite of the efficient rotation system there was a small group of masters who managed to hold on to their seats much longer than an average member of the board. But after I 540 their number decreased considerably since the government reduced the number of mandates drastically and decided autonomously who was to be appointed to an office on the board.

To summarize, the guild boards in the sixteenth century had neither a typically oligarchic nor a typically democratic character. The deans and jurors were mainly selected from among the well-to-do masters, but that did not mean less well-to-do masters were automatically excluded. For outsiders, social mobility was not restricted to obtaining the title of master. The highest positions on the board were also within reach of non-masters' children. A definite evolution can be observed in the course of time: whereas in the first decennia of the sixteenth century non-masters' children held at most a quarter of the mandates, their participation increased to 50,60 or even 70 per cent during the last fifteen years of that century.

The guilds of mercers, grocers, cheesemongers and stocking makers may be regarded as the most democratic associations in almost all respects: those were the guilds that were most open to outsiders, both within the guild itself and within the board. Moreover, those guilds were characterized by the lowest degree of monopolization among the board members. The least democratic guilds were those of the tailors and brewers. As far as the 
brewers' guild is concerned, this may be explained by the high degree of capital intensity and the limited employment opportunities that were typical of this branch of industry. The less democratic character of the tailors' guild may be connected with the fact that the masters were keen to have a seat on the board. Considering the market sector for which the tailors worked (the local market, a circle of well-to-do customers and custom-made clothes), it is evident that a position on the board could be advantageous to them, from an economic point of view. Without a doubt, however, it was the brewers' guild that underwent the most sweeping change. During the first four decades of the century it was a closed, hereditary association where power rested with a small group of families and where outsiders hardly stood a chance of being admitted; at the end of the century, however, it was an open guild that offered equal opportunities to non-masters' children and to masters' children to obtain a seat on the board.

On the basis of the houses in which masters lived, we were able to conclude that there were substantial differences between the guilds with regard to wealth and social status. The houses of brewers, for example, were almost three times as expensive as those of tailors. The choice of occupation was therefore of the utmost importance. Social differentiation and heterogeneity were typical of the guilds internally. The various social classes of society were represented in all the guilds. Still the group of grocers, cheesemongers and mercers included many more masters who belonged to the upper middle class, whereas the majority of tailors and stocking makers belonged to the lower middle class. The brewers' guild was characterized by the highest degree of social homogeneity. The majority of its masters belonged to the upper middle class. Our inquiry into the mobility of wealth and social prestige over two generations of craftsmen yielded remarkable results. It proved that there was no linear relationship between the duration of a career and a master's wealth and social position. Apart from the choice of occupation and a master's personal talents, social (relationships, a seat on the board, familial background) and economic factors (the economic climate) had much more influence on a master's wealth and social status than the number of years during which he practised his trade.

Our findings will prove most useful only when the comparative inquiry into upward social mobility within the European guilds of the early modern period has progressed further. It is remarkable how little material is currently available. An international data bank investigating social mobility should be established during the next few years. Just as the collection of data on prices and wages has proved to be useful for the study of the economic climate, so we are convinced that the collection of both quantitative and qualitative data on the conditions of admission and the number of registrations of masters, journeymen and apprentices in the guilds will lead to new perspectives with regard to the comparative inquiry into social mobility within the European guilds. 
APPENDIX I. NUMBER OF REGISTRATIONS OF NEW MASTERS IN THE MEMBERSHIP ROLLS OF THE GUILDS, I 500-I 600

\begin{tabular}{|c|c|c|c|c|c|c|c|c|c|c|c|c|}
\hline \multirow[t]{2}{*}{ Year } & \multicolumn{2}{|c|}{ Brewers } & \multicolumn{2}{|c|}{ Mercers } & \multicolumn{2}{|c|}{ Tailors } & \multicolumn{2}{|c|}{$\begin{array}{l}\text { Stocking } \\
\text { makers }\end{array}$} & \multicolumn{2}{|c|}{$\begin{array}{l}\text { Cheese- } \\
\text { mongers }\end{array}$} & \multicolumn{2}{|c|}{ Grocers } \\
\hline & non & mas & non & mas & non & mas & non & mas & non & mas & non & mas \\
\hline $1499-1500$ & 0 & 4 & 1 & 11 & 2 & 11 & - & - & - & - & - & - \\
\hline $1500-1501$ & 0 & 12 & 3 & 8 & 6 & 11 & - & - & - & - & - & - \\
\hline $1501-1502$ & 0 & 7 & 2 & 14 & 0 & 3 & - & - & - & - & - & - \\
\hline $1502-1503$ & 1 & 6 & 4 & 17 & 0 & 10 & - & - & - & - & - & - \\
\hline $1503-1504$ & 0 & 2 & 3 & 8 & 1 & 3 & - & - & - & - & - & - \\
\hline $1504-1505$ & 1 & 2 & 1 & 18 & 4 & 10 & - & - & - & - & - & - \\
\hline $1505-1506$ & 0 & - & 1 & 13 & 1 & 7 & - & _- & _- & - & - & - \\
\hline $1506-1507$ & 0 & 7 & 1 & 14 & 2 & 7 & - & - & _- & - & - & - \\
\hline $1507-1508$ & 0 & 3 & 3 & 32 & 7 & 13 & - & - & - & - & - & - \\
\hline $1508-1509$ & 0 & 8 & 1 & 29 & 2 & 11 & - & - & - & - & - & - \\
\hline $1509-1510$ & 0 & 7 & 5 & 24 & 3 & 6 & - & - & - & - & - & - \\
\hline $1510-1511$ & 0 & 18 & 5 & 20 & 2 & 7 & - & - & - & - & - & - \\
\hline $1511-1512$ & 0 & 11 & 2 & 13 & 3 & 9 & - & - & - & - & - & - \\
\hline $1512-1513$ & 0 & 4 & 8 & 36 & 3 & 11 & - & _- & - & - & - & - \\
\hline $1513-1514$ & 0 & 10 & 5 & 12 & 5 & 5 & - & _- & - & - & - & - \\
\hline $1514-1515$ & 0 & 14 & 3 & 21 & 0 & 20 & - & - & - & - & - & - \\
\hline $1515-1516$ & 0 & 9 & 4 & 33 & 4 & 9 & - & - & - & - & - & - \\
\hline $1516-1517$ & 0 & 10 & 5 & 29 & 2 & 8 & - & - & - & - & - & - \\
\hline $1517-1518$ & 0 & 4 & 4 & 39 & 4 & 15 & - & - & - & - & - & - \\
\hline $1518-1519$ & 0 & 13 & 8 & 9 & 1 & 12 & - & - & - & - & - & - \\
\hline $1519-1520$ & 0 & 4 & 6 & 24 & 2 & 13 & _- & - & - & - & - & - \\
\hline $1520-1521$ & 0 & 9 & 4 & 23 & 2 & 12 & - & - & - & - & - & - \\
\hline $1521-1522$ & 0 & 6 & 3 & 12 & 1 & 15 & - & - & - & - & - & - \\
\hline $1522-1523$ & 0 & 5 & 10 & 17 & 8 & 11 & - & - & - & - & - & - \\
\hline $1523-1524$ & 0 & 3 & 5 & 8 & 5 & 15 & - & - & - & - & - & - \\
\hline $1524-1525$ & 0 & 20 & 3 & 12 & 3 & 13 & - & - & - & - & - & - \\
\hline $1525-1526$ & 0 & 1 & 4 & 17 & 1 & 8 & - & - & - & - & - & - \\
\hline $1526-1527$ & 0 & 2 & 3 & 17 & 6 & 11 & - & - & - & - & - & - \\
\hline $1527-1528$ & 0 & 3 & 2 & 18 & 7 & 13 & - & - & - & - & - & - \\
\hline $1528-1529$ & 0 & 7 & 3 & 9 & 10 & 4 & - & - & - & - & - & - \\
\hline $1529-1530$ & 0 & 17 & 11 & 18 & 3 & 11 & - & - & - & - & - & - \\
\hline $1530-1531$ & 0 & 3 & 5 & 31 & 3 & 7 & - & - & - & - & - & - \\
\hline $1531-1532$ & 0 & 4 & 1 & 11 & 0 & 2 & - & - & - & - & - & - \\
\hline $1532-1533$ & 0 & 5 & 7 & 17 & 4 & 14 & - & - & - & - & - & - \\
\hline $1533-1534$ & 0 & - & 7 & 33 & 2 & 9 & - & - & - & - & - & - \\
\hline $1534-1535$ & 0 & 3 & 11 & 33 & 6 & 19 & - & - & - & - & - & - \\
\hline $1535-1536$ & 0 & 11 & 5 & 15 & 4 & 6 & - & - & - & - & - & - \\
\hline $1536-1537$ & 0 & 5 & 5 & 31 & 3 & 11 & - & - & - & - & - & - \\
\hline $1537-1538$ & 0 & 11 & 7 & 23 & 4 & 18 & - & - & - & - & - & - \\
\hline $1538-1539$ & 0 & 7 & 8 & 19 & 3 & 28 & - & - & - & - & - & - \\
\hline $1539-1540$ & - & - & - & - & 0 & 4 & - & - & - & - & - & - \\
\hline $1540-1543$ & 6 & 6 & 21 & - & 29 & - & 8 & - & 15 & - & 5 & - \\
\hline 1544 & 4 & 8 & 12 & - & 18 & 14 & - & - & 8 & - & 3 & - \\
\hline 1545 & - & - & 7 & - & 11 & - & 2 & - & 2 & - & 4 & - \\
\hline 1546 & 6 & - & 5 & - & 6 & - & - & - & 3 & - & 3 & - \\
\hline
\end{tabular}


Appendix I-continued

\begin{tabular}{|c|c|c|c|c|c|c|c|c|c|c|c|c|}
\hline \multirow[t]{2}{*}{ Year } & \multicolumn{2}{|c|}{ Brewers } & \multicolumn{2}{|c|}{ Mercers } & \multicolumn{2}{|c|}{ Tailors } & \multicolumn{2}{|c|}{$\begin{array}{c}\text { Stocking } \\
\text { makers }\end{array}$} & \multicolumn{2}{|c|}{$\begin{array}{l}\text { Cheese- } \\
\text { mongers }\end{array}$} & \multicolumn{2}{|c|}{ Grocers } \\
\hline & non & mas & non & mas & non & mas & non & mas & non & mas & non & mas \\
\hline 1547 & 6 & - & 11 & - & 19 & - & 3 & - & - & - & 3 & - \\
\hline 1548 & 4 & 7 & 6 & - & - & - & 2 & - & - & - & 1 & - \\
\hline 1549 & 2 & 7 & 8 & - & 12 & - & 6 & - & - & - & 4 & - \\
\hline 1550 & 2 & 2 & 7 & - & 12 & - & 2 & - & - & - & 4 & - \\
\hline 1551 & 2 & 1 & 9 & - & 8 & 11 & 7 & - & 5 & - & 2 & - \\
\hline 1552 & 3 & 6 & 5 & - & 12 & 9 & 3 & - & 3 & - & 4 & - \\
\hline 1553 & 3 & 2 & 3 & - & 10 & 20 & 3 & - & 0 & - & 1 & - \\
\hline 1554 & 3 & 14 & 8 & - & 11 & 7 & 5 & - & 2 & - & 6 & - \\
\hline 1555 & 2 & 7 & 9 & - & 7 & 20 & 2 & - & 1 & - & 2 & - \\
\hline 1556 & 1 & - & 11 & - & - & - & 2 & - & 12 & - & 6 & - \\
\hline 1557 & 4 & 4 & 5 & - & 1 & - & 5 & - & 4 & - & 7 & 6 \\
\hline 1558 & 5 & - & 4 & - & 1 & 14 & 7 & - & 3 & - & 4 & - \\
\hline 1559 & 4 & 7 & 8 & - & - & - & 11 & - & 4 & - & 4 & - \\
\hline 1560 & 5 & - & 14 & - & 1 & - & 11 & - & 3 & - & 7 & - \\
\hline 1561 & 0 & 11 & 11 & - & 5 & 2 & 12 & - & 5 & - & 5 & 3 \\
\hline 1562 & - & - & - & - & - & - & 13 & - & 3 & - & 5 & - \\
\hline 1563 & 2 & 3 & - & - & - & - & 10 & - & 5 & - & 3 & - \\
\hline 1564 & 4 & - & - & - & 1 & 7 & 3 & - & 1 & - & 8 & - \\
\hline 1565 & 2 & 4 & - & - & - & 23 & 5 & - & 4 & - & 4 & - \\
\hline 1566 & 3 & 5 & 6 & - & - & - & 8 & - & 9 & - & 3 & - \\
\hline 1567 & 3 & 7 & 11 & - & 1 & 4 & 18 & - & 6 & - & - & - \\
\hline 1568 & 1 & 3 & 6 & - & - & 11 & 6 & - & - & - & 7 & - \\
\hline 1569 & 6 & - & 10 & - & - & 23 & 6 & - & 6 & - & 3 & - \\
\hline 1570 & 5 & 2 & 7 & - & 11 & - & 6 & - & 4 & - & 5 & 10 \\
\hline 1571 & - & - & 12 & - & - & 5 & 5 & - & 0 & - & 9 & - \\
\hline 1572 & 0 & 3 & 9 & - & - & 5 & 4 & - & 0 & - & 4 & - \\
\hline 1573 & - & - & 16 & - & - & 26 & 17 & - & 8 & - & 8 & - \\
\hline 1574 & 5 & 6 & 22 & - & - & - & 2 & - & 6 & - & 5 & - \\
\hline 1575 & 5 & 3 & 20 & - & - & - & 8 & - & 8 & - & 8 & - \\
\hline 1576 & - & - & 27 & - & - & - & 14 & - & 6 & - & 10 & - \\
\hline 1577 Jan-Oct & - & - & 73 & - & 9 & - & 38 & - & 32 & - & 31 & - \\
\hline $1577-1578$ & 34 & - & 78 & - & - & - & - & - & 36 & - & 25 & - \\
\hline 1578-1579 & 0 & 10 & - & - & 4 & 1 & 7 & - & - & - & - & - \\
\hline 1579-1580 & 1 & 12 & 4 & - & 7 & 29 & 14 & - & - & - & - & - \\
\hline 1580-1581 & 1 & 15 & 6 & - & 1 & 9 & - & - & - & - & - & - \\
\hline 1581-1582 & 2 & - & 11 & 16 & 2 & - & 7 & - & - & - & - & - \\
\hline $1582-1583$ & 2 & 5 & 4 & 13 & 3 & 3 & 23 & 1 & - & - & - & - \\
\hline 1583-1584 & - & - & - & - & - & - & 9 & - & - & - & - & - \\
\hline 1584 Aug-Dec & - & - & - & - & 7 & - & 9 & - & 15 & - & 2 & - \\
\hline 1585 & 3 & 0 & 24 & - & 16 & 4 & 3 & - & 25 & - & 12 & - \\
\hline 1586 & 2 & 2 & 8 & - & 13 & - & 4 & - & 27 & - & 15 & - \\
\hline 1587 & 4 & 0 & 17 & - & 24 & 15 & - & - & 16 & - & 9 & - \\
\hline 1588 & 7 & 5 & 15 & - & 28 & - & 31 & - & 11 & - & 9 & - \\
\hline 1589 & 2 & 4 & 21 & - & 25 & - & 36 & - & 9 & - & 6 & - \\
\hline 1590 & 1 & 12 & 25 & - & 10 & - & 30 & - & 8 & - & 9 & - \\
\hline 1591 & 6 & 7 & 14 & - & 16 & - & 21 & - & 9 & - & 8 & - \\
\hline 1592 & 6 & 5 & 15 & - & 20 & 2 & 16 & - & 7 & - & 8 & - \\
\hline
\end{tabular}


Appendix I-continued

\begin{tabular}{lrrrrrrrrrrrrr}
\hline Year & \multicolumn{3}{c}{ Brewers } & \multicolumn{3}{c}{ Mercers } & \multicolumn{3}{c}{ Tailors } & \multicolumn{3}{c}{$\begin{array}{c}\text { Stocking } \\
\text { makers }\end{array}$} & \multicolumn{3}{c}{$\begin{array}{c}\text { Cheese- } \\
\text { mongers }\end{array}$} & Grocers \\
& non & mas & non & mas & non & mas & non & mas & non & mas & non & mas \\
& 2 & 12 & 27 & - & 24 & 4 & 5 & - & 5 & - & 2 & - \\
1593 & 2 & 6 & $*$ & - & 21 & 8 & 20 & - & 5 & - & 4 & - \\
1594 & 2 & 4 & 15 & - & 17 & 10 & 26 & - & 10 & - & 6 & - \\
1595 & 0 & 12 & 22 & - & 6 & 1 & 19 & - & 2 & - & 3 & - \\
1596 & 6 & 4 & 3 & - & 29 & 7 & 28 & - & 17 & - & 9 & - \\
1598 & 3 & 6 & 15 & - & 6 & - & 3 & - & 17 & - & 9 & - \\
1599 & 7 & 7 & 17 & - & 11 & 4 & - & - & 11 & - & 8 & - \\
1600 & 1 & 5 & 7 & 3 & 13 & 7 & 9 & - & 2 & - & 3 & - \\
Total & 194 & 528 & 910 & 820 & 617 & 737 & 574 & 1 & 400 & 0 & 335 & 19 \\
\hline
\end{tabular}

Sources: The City Archives of Ghent, series I60, no. 6; series I78, no. I; series I9I, nos I and 2; series 165 , no. 2; series $17 \mathrm{I} / \mathrm{I}$, no. I; series 172 , nos 3 and 4 .

Notes: The figures refer to the number of registrations of non-masters' children (non) and masters' children (mas).

Years without new masters are marked with a $\mathrm{o}$. Years for which no information is available are marked with a -.

Although 574 non-masters' children are registered in the rolls of the stocking makers' guild only 552 of them finally gained the master's title.

* The new members of 1594 are registered together with those of 1593.

During the period $1500-1540$ and during the Calvinist regime for most guilds the guild year began and ended in August, but for the tailors it began and ended in September. During the period I545-I577 and I584-I600 the new guild year began on Christmas Eve.

APPENDIX 2. NUMBER AND ANNUAL AVERAGE NUMBER OF REGISTRATIONS PER GUILD, I5OO-I60O

\begin{tabular}{|c|c|c|c|c|c|c|}
\hline & Brewers & Mercers & Tailors & $\begin{array}{l}\text { Stocking } \\
\text { makers }\end{array}$ & $\begin{array}{l}\text { Cheese- } \\
\text { mongers }\end{array}$ & Grocers \\
\hline \multicolumn{7}{|l|}{ Non-masters' children } \\
\hline No. of years* & 93 & 92 & 85 & 52 & 49 & 52 \\
\hline No. of registrations & 194 & 910 & 617 & 574 & 400 & 335 \\
\hline Annual average & 2.08 & 9.89 & 7.25 & 11.03 & 8.16 & 6.44 \\
\hline \multicolumn{7}{|l|}{ Masters' children } \\
\hline No. of years* & 82 & 43 & 71 & - & - & - \\
\hline No. of registrations & 528 & 820 & 737 & - & - & - \\
\hline Annual average & 6.43 & 19.06 & 10.38 & - & - & - \\
\hline \multicolumn{7}{|c|}{ Non-masters' children + masters' children ${ }^{* *}$} \\
\hline No. of years* & 75 & 40 & 65 & - & - & - \\
\hline No. of registrations & 610 & 967 & 1,042 & - & - & - \\
\hline Annual average & 8.13 & 24.17 & 16.03 & - & - & - \\
\hline
\end{tabular}

Sources: The City Archives of Ghent, series 160, no. 6; series 178, no. I; series I9I, nos I and 2; series 165 , no. 2; series I7I/I, no. I; series I72, nos 3 and 4 .

Note: * The figures refer to the number of years for which information is available.

** The figures refer to the number of years for which both the number of non-masters' children and the number of masters' children are known. 
APPENDIX 3. ANNUAL AVERAGE NUMBER OF

REGISTRATIONS PER POLITICAL PERIOD, I 50O-I6OO

\begin{tabular}{lccc}
\hline & Brewers & Mercers & Tailors \\
\hline $1500-1540$ & 7.3 & 24.2 & 13.7 \\
$1540-1577$ & 8.0 & - & 18.2 \\
$1578-1584$ & 12.0 & 22.0 & 14.3 \\
$1584-1600$ & 9.7 & - & 24.3 \\
\hline
\end{tabular}

Sources: The City Archives of Ghent, series I60, no. 6; series 178, no. I; series I9I, nos I and 2. Note: The figures are calculated on the basis of the years for which both the number of masters' children and non-masters' children are known. 